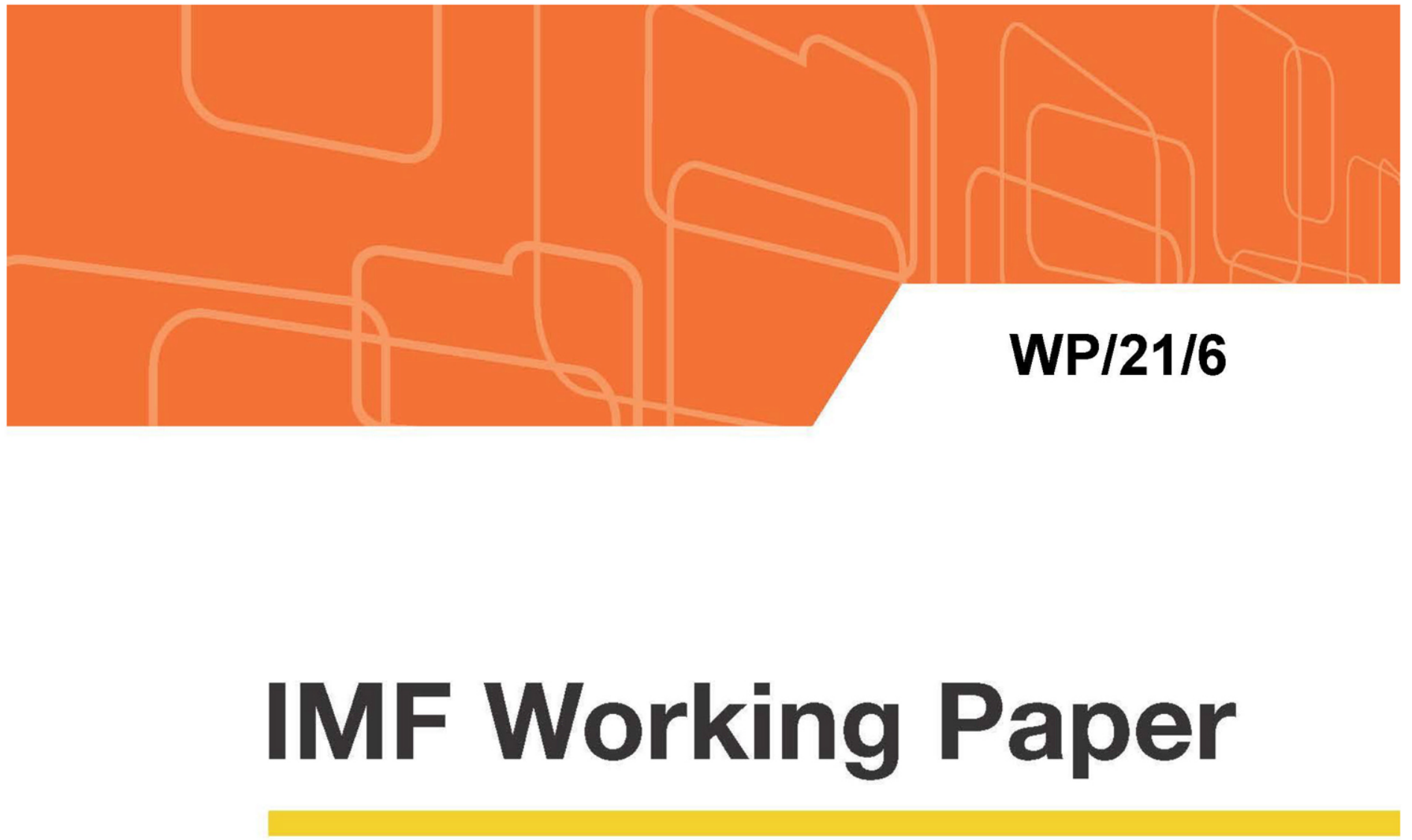

\title{
Some Alternative Monetary Facts
}

Peter Stella, Manmohan Singh and Apoorv Bhargava

IMF Working Papers describe research in progress by the author(s) and are published to elicit comments and to encourage debate. The views expressed in IMF Working Papers are those of the author(s) and do not necessarily represent the views of the IMF, its Executive Board, or IMF management. 


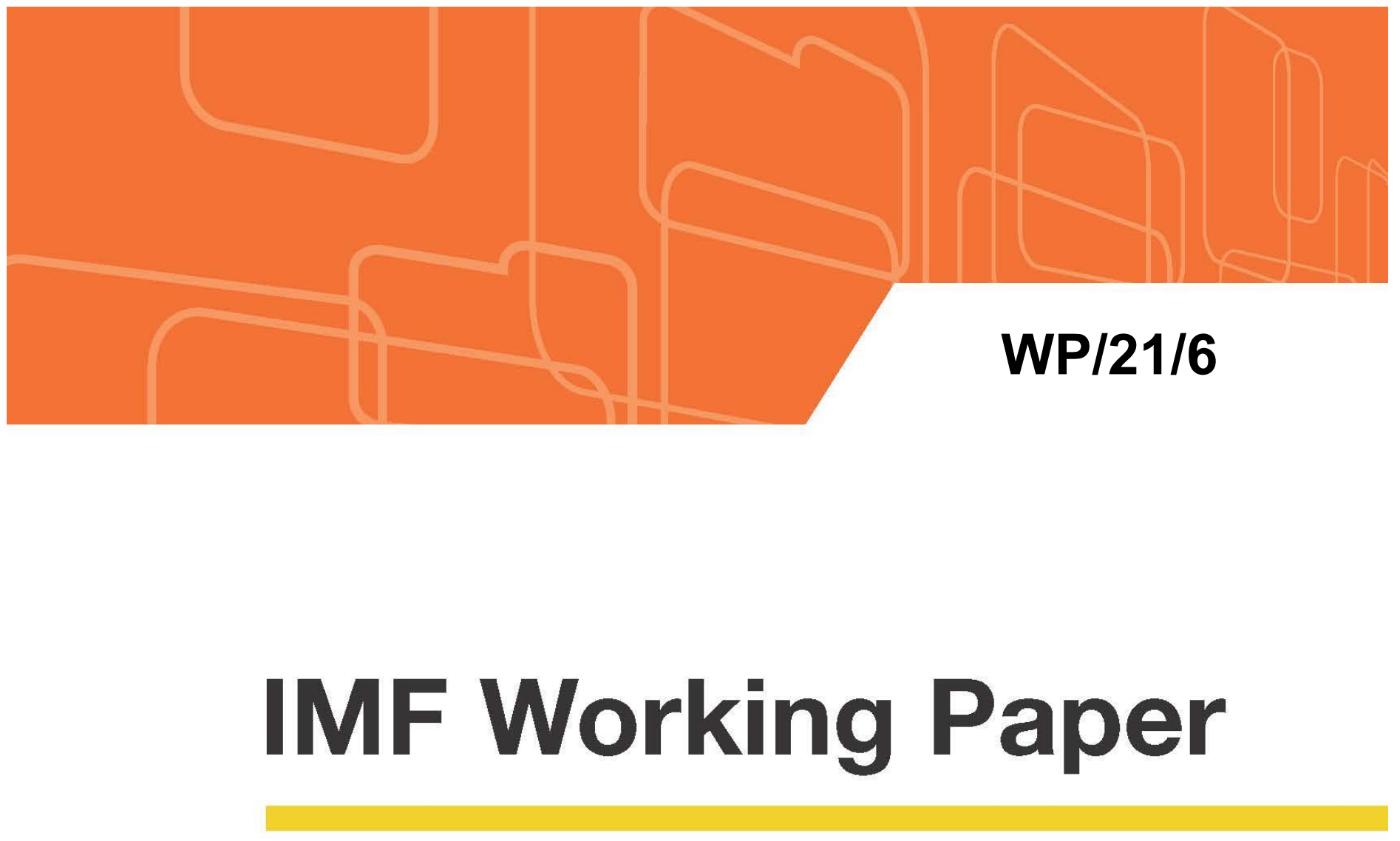

\section{Some Alternative Monetary Facts}

Peter Stella, Manmohan Singh and Apoorv Bhargava

IMF Working Papers describe research in progress by the author(s) and are published to elicit comments and to encourage debate. The views expressed in IMF Working Papers are those of the author(s) and do not necessarily represent the views of the IMF, its Executive Board, or IMF management.

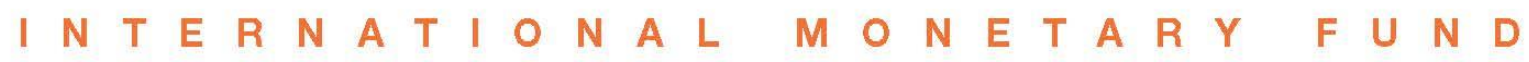




\title{
IMF Working Paper
}

Monetary and Capital Markets Department

Some Alternative Monetary Facts

Prepared by Peter Stella, Manmohan Singh and Apoorv Bhargava

Authorized for distribution by Jihad Alwazir

January 2021

IMF Working Papers describe research in progress by the author(s) and are published to elicit comments and to encourage debate. The views expressed in IMF Working Papers are those of the author(s) and do not necessarily represent the views of the IMF, its Executive Board, or IMF management.

\begin{abstract}
In this paper, we discuss the modern history of monetarism and its alternatives, as well as the changing empirical relationship of various measures of money and inflation. After demonstrating that previous naïve correlations between money and inflation as established in the $20^{\text {th }}$ century literature have largely disappeared, we explain why this cannot be taken as support for an increased reliance on permanent monetary finance. Rather, we argue that rapid technological innovation in payments systems - both public and private - including in global pledged collateral markets, portends a declining demand for central bank liabilities.
\end{abstract}

JEL Classification Numbers: G21; G28; F33; K22; G18; G15

Keywords: money aggregates; inflation; monetary financing; central bank balance sheet Author's E-Mail Address: msingh@imf.org; abhargava@imf.org; pstellaconsult@gmail.com 
Abstract

Introduction $\underline{4}$

I. Quantity theory of Money_-The Last 50 Years (Theory) .......................................... 7

A. Equation of Exchange .............................................................................

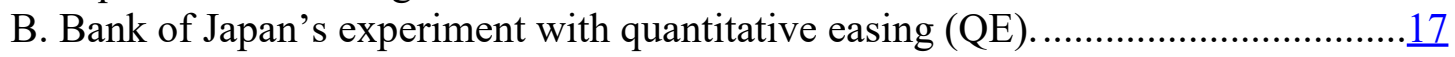

II. Quantity theory of Money - the Last 50 Years (Empirics) .......................................... 22

A. Revisiting Alternative Monetary Facts ……..................................................

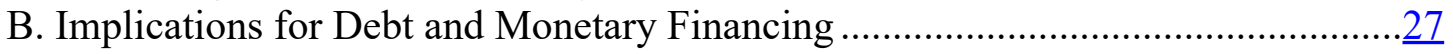

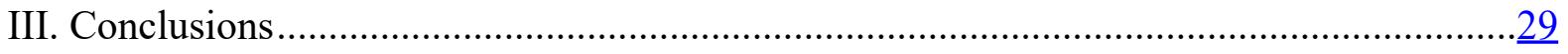

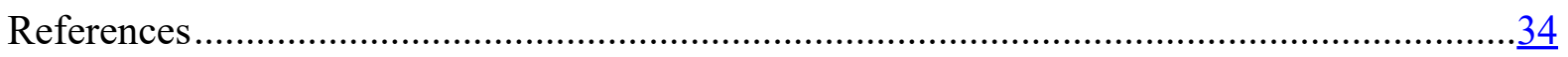

Tables

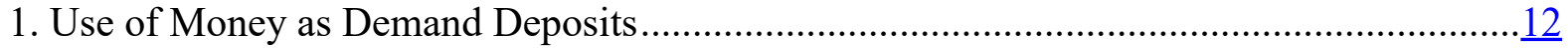

2. Long-term Geometric Growth Rates of MS (and Components) and Inflation ....................24

3. Long-term Geometric Growth Rates of MS (and Components) and Inflation (Correlation

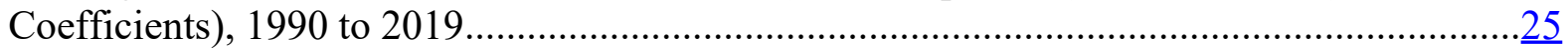

4. Long-term Geometric Growth Rates of MS (and Components) and Inflation (Correlation

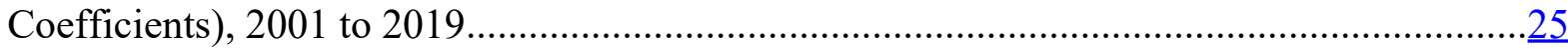

Figures

1. Correlation of Monetary Aggregates with Inflation for Japan (1990-2019)......................18

2. Japan: Bank Reserves and Total Loans 1991-2020 (in 100 billion yen) ..........................19

3. Japan: Change in Total Loans and in Bank Reserves (12 months prior) 1991-2020 ..........20

4. 10 Year Japan Government Bond (JGB) Yields .........................................................21

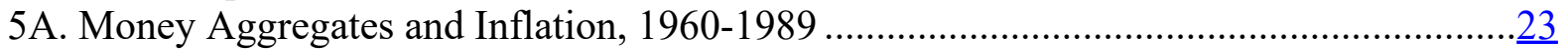

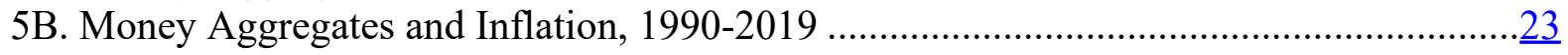

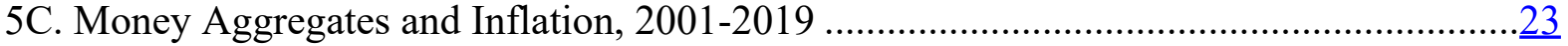

A1. IS/LM Model A2. Contraction in collateral ....................................................

Annexes

1. Collateral and Money Aggregates 


\section{INTRODUCTION}

The massive expansion of central bank balance sheets since 2009 in countries with welldeveloped financial markets has not yet led to accelerating inflation. ${ }^{1}$ Nonetheless, the resurgence of central bank balance sheet growth and increase in monetary aggregates associated with policy responses to the COVID-19 crisis has reignited an intense debate as to whether current central bank actions will cause a spike in inflation if not swiftly reversed.

There are prominent voices on diametrically opposed sides of this argument. Some advocate that central bank balance sheet expansion be curtailed to short circuit money growth and inflation. Others, some associated with so called "modern monetary theory" advocate increased reliance on monetary (vs debt) finance not only during the COVID crisis but also to fund future large-scale public investment projects. They believe that there remains ample scope to employ monetary finance without inflationary consequences.

In this paper we revisit the issue of the relation between money and inflation in light of the evidence of the past several decades - in essence reopening a discussion that many people believe was definitively closed decades ago, a discussion some believe was "won" by the monetarist argument epitomized by the pithy remark "inflation is always and everywhere a monetary phenomenon". ${ }^{2}$ For example:

"The long-run relationship between money and prices is ...well-understood...the inflation rate is essentially equal to the growth rate of the money supply minus the growth rate of output. There is widespread consensus in the profession that successfully stopping inflation involves substantial reductions in money growth rates.",3

In fact, that debate was never closed and by 2007 both the consensus academic and central banking views of the world were that monetary policy works through changes in interest rates and that monetary quantities are virtually irrelevant in conducting monetary policy. ${ }^{4}$

“...once we recognize that money is fundamentally endogenous, analytical thought experiments that assume an exogenous change and trace its impact are not that helpful, if not meaningless. They obscure, rather than illuminate, the mechanisms at work." 5

"A textbook money multiplier and the bank lending channel imply an important role for money in the transmission mechanism. In the past couple of decades however, New Keynesian models used for macroeconomic policy analysis have excluded money. "6

\footnotetext{
${ }^{1}$ Hereafter, when we mention "central banks" we refer primarily to central banks in those countries.

${ }^{2}$ Friedman (1998)

${ }^{3}$ Marcet and Nicolini (2003), p. 1476.

${ }^{4}$ See Bernanke (2006), Borio, Bindseil,

${ }^{5}$ Borio (2009), p. 14.

${ }^{6}$ Carpenter and Demiralp (2012).
} 
If we put this argument in its sharpest relief, there are those who believe inflation and its impact on macroeconomic variables is always and everywhere about monetary growth and those who believe that monetary quantities play no independent role whatsoever in determining macro variables.

A key point of contention between the two views centers on whether the quantity of money is exogenous - determined by the state (central bank and treasury), or endogenous - determined by private sector demand and supplied passively by the state.

We may make more precise the point of contention by noting that the state can only directly control the forms of money it issues, i.e. currency and deposits held by the private sector at the central bank. ${ }^{7}$ Since central banks routinely provide as much physical currency as the market desires, the issue is whether the state determines the amount of private sector deposits held at the central bank-usually synonymous with bank reserves. ${ }^{8}$

Despite the persistence of monetarist theories that stress the exogeneity of the monetary base, there is ample evidence that until the Global Financial Crisis (GFC) central banks provided the quantity of reserves demanded by banks, neither directly nor indirectly aimed at monetary aggregate targets and used interest rates rather than quantitative policy instruments. ${ }^{9}$ So why we are writing this paper?

There are several important motivations for revisiting, now, the theoretical and empirical nature of the relationship between money and inflation:

- Even if the monetarist conception of the relation between money and inflation is faulty, it is evident that many people believe it is broadly correct. By "believe" we mean acting as if their view is correct even if they are not completely certain. Models with people holding heterogenous views allow for multiple equilibrium and learning. In this case, if enough people believe in the monetarist view, inflation expectations may rise absent fundamental reasons for doing so with consequences for nominal interest rates on newly issued government debt. If the state does not subsequently validate expectations of higher inflation, the real rate on government debt will be higher than it would otherwise be. Thus, the state is confronted with the choice of higher-than-desired inflation or a higher than desired real debt cost. We aim to make a modest contribution toward altering views toward the non-monetarist interpretation

\footnotetext{
${ }^{7}$ This concept is variously called "central bank or outside money", M0, "high powered money", and the "monetary base".

${ }^{8}$ Though some central banks provide deposit facilities to certain nonbanks the latter are rarely significant from a macro standpoint and will be ignored here.

${ }^{9}$ Japan, which started to experiment with balance sheet expansion in 2001 is the obvious exception to this statement.
} 
of inflation and thus lessen the probability of an adverse equilibrium driven by false model expectations. ${ }^{10}$

- Shortly after the peak of the financial market turbulence associated with the GFC, 2008-09, the process by which central banks ${ }^{11}$ supplied monetary base changed. As noted above, central banks had been providing the quantity of currency and reserves ${ }^{12}$ required by households $(\mathrm{HH})$ and banks respectively, while targeting short term interest rates. Thus "monetary policy" was "interest rate policy" and money was an endogenous variable with little import for policy. Since 2009, the quantity of monetary base in floating exchange rate regimes has been determined by central bank asset purchases, it has thus become "exogenous". The exogeneity of the monetary base being a key foundation of the monetarist model, it is possible this regime change has altered the relationship of money and prices toward a more monetarist view. It is thus important to re-examine the debate in the context of the new reality of exogenous money.

- If, upon re-examination, there continues to be no reason to expect money growth to be correlated with higher inflation this might lead some to conjecture that outright money creation is essentially a costless way to finance government spending. If there are no inflation consequences of rapid money growth, as it so seems, why not finance fiscal deficits with money rather than debt? ${ }^{13}$ This notion underpins the current popularity of "helicopter money". As we believe the development of modern financial markets completely invalidates this view, it is important to articulate the key difference between endogenous money growth and exogenous monetary finance and spell out why and when monetary finance is inflationary.

In this paper, we discuss the modern history of monetarism and its alternatives, as well as the changing empirical relationship of various measures of money and inflation. After demonstrating that previous naïve correlations between money and inflation in the $20^{\text {th }}$ century have largely disappeared, we explain why this cannot be taken as support for an increased reliance on permanent monetary finance. Rather, we argue that rapid technological

\footnotetext{
${ }^{10}$ See Evans and Honkapohja (2003), "Our findings show the importance of conditioning policy appropriately, not just on fundamentals, but also directly on observed households and firm expectations", See also Evans and Honkapohja (2001).

${ }^{11}$ Once central banks reached the effective lower bound on nominal interest rates, they purchased assets in unconventional policy actions and allowed the corresponding excess bank reserves created to remain in the system. Thus, the banking system held substantially more "excess reserves" than had heretofore been demanded for settlement of interbank payments.

12 Teles, Uhlig, and Azevedo (2015)

${ }^{13}$ Drastic changes in central bank operations and monetary institutions in recent years have made previously standard approaches to explaining the determination of the price level obsolete. Recent expansions of central bank balance sheets and of the levels of rich-country sovereign debt, as well as the evolving political economy of the European Monetary Union, have made it clear that fiscal policy and monetary policy are intertwined. Our thinking and teaching about inflation, monetary policy, and fiscal policy should be based on models that recognize fiscal-monetary policy interactions (Sims, 2013).
} 
innovation in payments systems - both public and private-including in global pledged collateral markets, portends a declining demand for central bank liabilities.

In this paper, Section II discusses the modern history of monetarism and its alternatives, Section III looks at the changing empirical relationship of various measures of money and inflation. Section IV concludes that a government strategy that relies increasingly on permanent monetary finance will be tested, given the experience in emerging markets.

\section{QUANTITY THEORY OF MONEY-THE LAST 50 YEARS (THEORY)}

The key set of interrelated propositions that support the quantity theory of money (QTM) are (i) the proportionality of money and prices, (ii) the exogeneity of the nominal stock of money and its causal role in the monetary transmission mechanism, (iii) the monetary theory of the price level and (iv) the neutrality of money. ${ }^{14}$

\section{A. Equation of Exchange}

The revival of the QTM is most strongly associated with Milton Friedman and though monetarism was identified as "anti-Keynesian", these two titans of the $20^{\text {th }}$ century both seemed to have believed in versions of it. Of the Quantity Theory of Money, J.M. Keynes was to say in A Tract on Monetary Reform "The truth of this, properly explained and qualified, it is foolish to deny". ${ }^{15}$

Yet there is an important difference between the QTM at the time of Keynes' remark, 1924, and the QTM "revived" by Friedman. ${ }^{16}$ The original assertions of the QTM, before the development of formal sophisticated mathematical models, and before the development of economic statistics, described a relationship between money and payments or transactions (not national income). That is, the theory was developed well before the development of modern national and income statistics and before reliable statistics on financial transactions. Put simply, the quantity of money (however defined) was related to the value of economic payments - being the sum of payments made in bond, stock, and foreign exchange trading, real estate transactions, tax payments, wholesale and intermediate trade, etc. as well as payments for what we would call today final goods and services.

The first formalization of the theory was the "Equation of Exchange", more a tautology than a theory..$^{17}$ If one calculates the total value of all monetary transactions effected during a period of time divided by the average money stock during that period of time one can derive a "turnover" rate of money per period of time, often called "velocity" signifying the rate at which monetary objects circulate within the economy. Since velocity cannot be independently observed, the equation of exchange was essentially a definition of velocity.

\footnotetext{
${ }^{14}$ See Humphrey (1974).

${ }^{15}$ Keynes (1924), page 42.

${ }^{16}$ See Patinkin (1969) for an interesting interpretation of Friedman's role within the Chicago School and whether he diverged from his predecessors vis-à-vis monetary theory.

${ }^{17}$ See Bordo (1987).
} 
Starting from this definition of velocity, theorists posited that velocity was either constant or could be taken as constant over short periods of time owing, as Keynes said, to "certain habits of business and banking". This enabled thought experiments involving the reaction of total payments to exogenous changes in money.

Since the time of Hume (mid-1 $8^{\text {th }}$ century) it was generally believed, though not unanimously, that exogenous changes in the quantity of money led to changes in economic activity in the short run but only nominal (price) changes in the long run. Yet the development of price indices, measures of real economic activity and the determination of some notion of the "short" run and "long" run had to await the development of systematic data and methods of analysis while working out the theoretical basis explaining short and long run dynamics required advancements in mathematical modeling.

As economic statistics began to be precisely defined and consistently collected, new methods of statistical analysis enabled economists to make tentative steps to parameterize and test the QTM against available data. There was also a subtle but decided pivot away from considering the theory as applying to all economic payments to applying it only to national income or output. That is, in the revived QTM money was related to expenditures only on final goods and services. What explains this pivot?

Although there are several ex post justifications for using national income and/or value added (GDP or GNP) in QTM equations the most plausible ex ante reason is simply the difficulty in developing the requisite statistics for measuring economy-wide transactions and, more importantly, a transactions based price index. Such an index would have weights for transactions in financial markets, wholesale markets, and other high frequency trading markets that would dominate payments for final goods and services.

Once the economic statistics were developed and tentative empirical relationships were established between measures of money, income, and prices, both monetarism and Keynesians focused on the income approach to the QTM. It is important to note that the definitions of money, income and prices were not developed completely independently.

Friedman and Schwartz played an important role in defining "the" monetary aggregates and they took a quite pragmatic approach. Reading their discussion about whether government deposits should be part of M1 and the monetary base it is evident that they had no ideological nor predetermined theoretical view of the matter, it simply was their observation that such government deposits were volatile and not well correlated with prices and income that led them to exclude them from measures of monetary aggregates.

Thus, the Equation of Exchange,

$\mathrm{MV}(\mathrm{t})=\mathrm{P}(\mathrm{t}) \mathrm{T}$ as expressed for example in Fisher (1922) was transformed into

$\mathrm{MV}(\mathrm{y})=\mathrm{P}(\mathrm{y}) \mathrm{Y}$ in the conventional monetarist formulation or, $\mathrm{M}=\mathrm{k}(\mathrm{y}) \mathrm{P}(\mathrm{y}) \mathrm{Y}$ in the "Cambridge $\mathrm{k}$ " formulation. 
The pivot replaced all payments in the equation with payments for final goods and services - both notionally divided into real and price components.

Although this was convenient for empirical work, and (income) velocity could be defined just as easily as (transactions) velocity in the equation of exchange, it created a new conceptual difficulty. Since money is used for many more transactions in more markets than just that for final goods and services, the ratio of national income to money, income velocity, is not a meaningful statistic. That is, it cannot be thought of as the turnover ratio for money in that market. If it were possible to identify money used only in those transactions, we could think of velocity as representing a relatively fixed technology of payments in that market. But this is not possible.

There are several possible responses to this problem One is simply to ignore it and implicitly assume that transactions and income velocity are the same. That is, assume that the ratio of national income to money used in paying for final goods and services is the same at the ratio of all payments to all money. That this is not remotely true will be evidenced somewhat later in the paper. At this point it is worth noting that the ratio of national income in the United States to currency, which is primarily used for payments of final goods and services was about 18 while the ratio of U.S. interbank payments to bank reserves (exclusively used in interbank payments) was 77,874 in 2007. Each of these separate statistics might reasonably be thought indicative of the intensity of money use in each market but mixing them together is nothing short of odd.

An alternative approach to this quandary is to reinterpret the QTM as a money demand function coupled with an exogenous supply of money. Arithmetically, this is the "Cambridge $\mathrm{k}$ " solution. Dividing both sides of the conventional formulation by V and calling $1 / \mathrm{V}$, $\mathrm{k}$, we can interpret $\mathrm{k}$ as a vector of coefficients in a money demand function where there is a linear or log linear relationship between money and income.

Although the Cambridge approach is more intuitive and easier to teach with analogies to personal experience, an average person holds a certain amount in liquid assets for consumption purposes during the weeks between paychecks. It does not solve the fundamental problem that the vast majority of payments are made by financial corporations and banks, not by individuals, the types of money they use are different as are the payments systems with very different velocities.

Both formulations relied on $\mathrm{V}$ or $\mathrm{k}$ to be a stable function of a small number of variables over a reasonably long time. Thus a comparative static exercise where $\mathrm{M}$ is exogenously altered, taking $\mathrm{V}$ or $\mathrm{k}$ to be constants (payments systems technology and business customs fixed), and real income to be determined by real rather than nominal factors (output fixed suggest long run money neutrality) - yields proportionality between the quantity of money and the GDP or national income ${ }^{18}$ price deflator. In both interpretations, the relationship is between money and income, not transactions.

\footnotetext{
${ }^{18}$ In theory, the value of Gross Domestic Income and Gross Domestic Product are equal so either could be used in the QTM and in empirical work. The U.S. Bureau of Economic Analysis considers GDP to be a more reliable
} 
Nevertheless, there were consequences of the different formulations in the way the two schools viewed model dynamics and policy options. By emphasizing velocity or the turnover rate of money as primarily a technological phenomenon not likely to change rapidly, monetarists were more inclined to view changes in money as exogenous and driving income. Keynesians, viewed "k" as a portfolio balance parameter - people and firms tend to hold a certain fraction of income in money for transactions purposes, and were more apt and willing to see changes in nominal income as the force driving the quantity of money in the system, i.e. that money was endogenous. They were also less concerned with the mechanics of how the central bank could indirectly control the supply the money through alterations in the supply of bank reserves - the so-called "money multiplier".

Returning to the difference between all transactions/payments vs payments for only goods and services, both schools failed to foresee the extraordinary technological changes... or what Keynes referred to as "certain habits of business and banking" that would invalidate the QTM proportionality hypothesis, first in the wholesale payments spheres and then in retail payments. ${ }^{19}$

Were there a stable relationship between total payments and payments for final goods and services and between the two velocities, i.e. similar or a stable difference in the technical efficiency of the systems used for total and final goods and services payments, the empirical relationships found in one would be reliable proxies for the other.

As presaged above, neither of these propositions is remotely true. Trading in financial markets since the 1950s has grown much faster than the real economy and the technology employed to make payments in those markets has advanced far beyond that in everyday retail markets. The discrepancy between the demand for the types of money used in retail payments and in total payments (primarily financial) is one of the several reasons we will employ to resolve the surprising development of monetary facts in the last few decades. Not only have wholesale payments - effected with bank reserves - been subject to enormous gains in speed and efficiency, retail payments, apart from those made with currency, have also exhibited an acceleration in speed in the advanced countries since the $1980 \mathrm{~s}$.

Although exponentially more payments are made in all transactions than in the acquisition of final goods and services the quantity of balance sheet money being used to make those payments is falling in comparison to money-such as currency-used in retail markets. This

measure of output than GDI as it considers the source data underlying GDP to be more timely and accurate. See BEA (2007), p.22. Empirical work will usually employ GDP. As it is easier to motivate the demand for money as relating to spending and income, rather than to output, it is common in conceptual discussions to consider the demand for money as directly related to income rather than output. In Lucas (1972), e.g., individuals first receive money/income, then spend it, leading to an increase in nominal output.

${ }^{19}$ That wholesale payments systems were the first to experience technological change is not surprising as the fixed costs of adopting innovating technology could be spread over a much higher value of payments. JPMorgan, one of the leading adopters of blockchain technology reportedly handles the equivalent of US\$ 6 trillion in cross-border payments daily - the initial target market for its JPM Coin. See Son (2020). For an insightful treatment of technological innovation in general see Christensen (1997). 
has led to a stunning divergence in the intensity of money use for all transactions compared with the velocity of money calculated in conventional money demand functions.

We will discuss the importance of this fact more thoroughly in Section III but to give an idea of the trend in payments speed and efficiency during the $20^{\text {th }}$ century we provide a set of facts describing U.S. wholesale payments (through the Federal Reserve's Fedwire transfer system) and U.S. retail payments (made with demand deposits (DD)).

Payments in the main interbank wholesale markets in the U.S., UK, and Eurozone (Fedwire, CHIPS, CHAPS, and TARGET2) are approximately 50X payments made for final goods and services in those economies. ${ }^{20}$ Since those wholesale payments are only a fraction of total payments made in those economies it is easy to surmise that payments for final goods and services, roughly equal to national income and national value added, comprise less than one percent of total payments. Interpreting the price index of a truly transactions-based index, were it calculable, would be extraordinarily difficult. Thus, the pivot away from transactionsbased views of the QTM toward income-based views may have been a practical matter of using the data available and re-conceptualizing the theory in line with Friedman's work relating the consumption function to permanent income.

As an aside, the recent trend to examine the macro stability consequences for ultra-loose monetary policy on financial market prices and the related issue of such policies on income distribution, rather than on the consumer price index (see IMF and BIS) is in some sense a return toward looking at the impact of monetary policy on prices that are orthogonal to nominal national income and value added. This has led to active debates over whether central banks should target financial market prices in addition to retail prices and incomes.

Keynes (1924) was already alert to the idea that important real consequences could lie beneath a seemingly innocuous change in the general price level, "...a change in the value of money, that is to say in the level of prices, is important to Society only in so far as its incidence is unequal. Such changes have produced in the past, and are producing now, the vastest social consequences, because, as we all know, when the value of money changes, it does not change equally for all persons or for all purposes".

Until 1996 the Federal Reserve Board published statistics on U.S. DD debits as well as the annual deposit turnover ratio, i.e. total debits made during the year divided by the average DD balances held during the corresponding year at U.S. banks. ${ }^{21}$ In the table below, several interesting facts illustrate the impact technological innovation has had on the use of "money" in the form of DD. Table 1 is illustrative. In the left-most column, we show GDP divided by M1 which is the conventional income velocity of M1. From 1927 to 1977 it is remarkably stable, between 3 and 5. In the 1980s M1 velocity begins to rise as the ratio of GDP to DD rises considerably (U.S. DD velocity doubles during this period).

\footnotetext{
${ }^{20}$ The sum of payments effected in 2017 through the two U.S. large value transfer systems alone (Fedwire and CHIPS), was 1 quadrillion 133 trillion dollars compared with U.S. GDP that same year of US\$19.5 trillion.

${ }^{21}$ See Garvy (1959) for an excellent discussion of this data.
} 


\begin{tabular}{|c|c|c|c|c|c|c|c|}
\hline \multirow{4}{*}{ Year } & \multicolumn{7}{|c|}{$\begin{array}{c}\text { Bank Debits and Deposit Turnover Excluding Interbank Deposits and Collection Items, at } \\
\text { all commercial banks, } \\
\text { (annual data, 1919-1941) }\end{array}$} \\
\hline & \multirow[t]{3}{*}{ GDP/M1 } & \multirow[t]{3}{*}{ GDP/DD } & \multirow{3}{*}{$\begin{array}{l}\text { ALL } \\
\text { DEBITS/GDP }\end{array}$} & \multirow[t]{3}{*}{ GDP } & Turnover & \multirow{2}{*}{\multicolumn{2}{|c|}{$\begin{array}{l}\text { Value In } \$ \text { billions } \\
\text { All Banks }\end{array}$}} \\
\hline & & & & & \multirow{2}{*}{\multicolumn{3}{|c|}{$\begin{array}{l}\text { All Banks } \\
\text { DD Debits }\end{array}$}} \\
\hline & & & & & & & \\
\hline 1927 & 4 & 5 & 9 & 104.6 & 41 & 22.3 & 915 \\
\hline 1937 & 3 & 4 & 7 & 93.0 & 25 & 25.7 & 635 \\
\hline 1947 & 3 & 4 & 4 & 249.6 & 19 & 59.0 & 1104 \\
\hline 1957 & 4 & 6 & 5 & 474.0 & 31 & 76.5 & 2357 \\
\hline 1967 & 5 & 7 & 8 & 860.0 & 57 & 123.2 & 6666 \\
\hline 1977 & 5 & 7 & 21 & 2081.8 & 146 & 292.2 & 42722 \\
\hline 1987 & 9 & 14 & 46 & 4855.2 & 623 & 355.7 & 221729 \\
\hline 1996 & 9 & 17 & 58 & 8073.1 & 922 & 472.2 & 468571 \\
\hline
\end{tabular}

Source: Federal Reserve and IMF Staff estimates

The dramatic change shown above is in the DD turnover ratio. This is the ratio of all payments made with DD divided by the average DD balance during the year. The ratio falls from 41 prior to the Great Depression and does not regain that level until the 1960s. From then on it rises sharply to 922 in 1996, the year the Federal Reserve ceased publishing the data. A turnover ratio of 922 on an annual basis implies, given approximately 250 business days per year, that the average deposit balance turns over almost 4 times per day. Clearly the intensity of use of DD, or if we wish to state it this way, the transactions velocity of DD is hardly stable, rising exponentially during the last decades of the $20^{\text {th }}$ century. ${ }^{22}$

Total payments made with DD, the last column to the right, were 58x U.S. GDP in 1996. If we assume that 85 percent of U.S. GDP was then purchased with debits of U.S. DD, only 1.5 percent of all payments made with DD were then made for the acquisition of final goods and services.

We will discuss the issue of the different velocities of currency (C) and DD later in Section III. For now, it suffices to note that the income velocity of currency has not been rising in the United States during the last half of the $20^{\text {th }}$ century meaning that the proportion of currency in M1 has consistently been rising. Indeed, C exceeded DD in M1 in the U.S. in 1997 and remained so for twenty years - $C$ was more than double DD just before the GFC in 2007-08 Thus the apparent stability of M1 velocity has been somewhat of an illusion, the stable or declining velocity of $\mathrm{C}$ combined with a relative growth of $\mathrm{C}$ in $\mathrm{M} 1$ has subdued the income velocity of M1 despite the phenomenal increase in DD transactional velocity.

Turning to wholesale payments, in 1947, US\$ 316 billion in payments were made through Fedwire during which time the stock of reserves held at the FRBs was US\$ 17.9 billion

\footnotetext{
${ }^{22}$ Among the reasons are technological innovation, deregulation and the development of the eurocurrency markets.
} 
yielding an annual turnover of 58. In 2007, US\$ 670.7 trillion in payments were made through Fedwire while reserves amounted to US\$ 9.0 billion yielding an annual turnover of 77,784. Put differently, payments increased by 212,115 percent while reserves fell by 50 percent. There is no significant positive correlation between U.S. total reserve balances and any economic variable.

Thus, we see that various subcomponents of two measures of money, M0 and M1 have wildly different "velocities" and stability properties. In the former, between $\mathrm{C}$ and reserves, and in the latter, $C$ and DD. In both cases the stability of the relationship between $\mathrm{C}$ and income - a stable currency "velocity", combined with vast improvements in the speed and efficiency of the use of reserves and DD has led $\mathrm{C}$ to dominate proportionally the composition of $\mathrm{M} 0$ and $\mathrm{M} 1$.

M0 is the key monetarist variable as it is notionally controlled by the central bank and thus exogenous. Its importance may be judged by the various evocative names given it my monetarists. One is "base money"- the sum of bank deposits at the central bank and currency in circulation. ${ }^{23}$ In talking about the monetary base, Friedman described it as "highpowered" money, a liability of the government forming a base upon which the financial sector builds broader measures of money. Friedman, coming from an empirical perspective, made what he saw as a crucial distinction between "high powered" money and bank money. High powered money serves as "... reserves for the banks and as the basis for a much larger addition to the quantity of money". ${ }^{24}$ Friedman also described base money as "outside" money. Here we wish to discuss the importance of the technological workings of payments systems and the debate over whether central bank direct liabilities (CBDL) are exogenous or endogenous. ${ }^{25} \mathrm{CBDL}$ here refers to currency and bank deposits (reserves).

By 2007, C represented about 98 percent of M0 although we estimate it at most was involved in US\$ 2 trillion in payments that year while payments made through the two U.S. LVPS (Large Value Payments System), Chips and Fedwire, during the same year amounted to US\$ 1 quadrillion 156 trillion. ${ }^{26}$ Given a 2007 average stock of U.S. currency outstanding of US\$ 811.7 billion and assuming 50 percent is held outside the United States, this gives an annual turnover ratio of currency of about 5. The average 2007 stock of reserves was US\$ 8.6 billion $^{27}$ giving a gross LVPS turnover ratio of 134,453 per year.

\footnotetext{
23 "In circulation" means in the hands of the public, i.e. having been paid out and duly recorded by the central bank. It thus includes notes in mattresses, buried underground or destroyed as well as those being used. The total in circulation is, of course, reduced when the central bank destroys unfit notes.

${ }^{24}$ Milton Friedman, Money Mischief, page 206.

${ }^{25}$ For the remainder of the paper we eschew the terms "monetary base", "high-powered money", "outside money", etc., as being rhetorically biased toward the monetarist view that CBDL are "special and powerful".

${ }^{26}$ Assuming $\mathrm{C}$ accounts for 15 percent of purchases of final goods and services and summing up the transactions executed through CHIPS and Fedwire in 2007. The 2015-16 U.S. Diary of Consumer Payment Choice estimates that by value, $\mathrm{C}$ accounts for 7.9 percent of consumer payments. See FRB Boston, et. Al. (2017).

${ }^{27}$ Numbers for average currency in circulation and reserves are from the FRB St. Louis online database FRED.
} 
This rather stunning fact leads us to the notion of the "money multiplier", that is, the link between bank reserves and the various monetary aggregates. To explain the exogeneity of money in the context of developed markets, monetarists needed to link the only plausibly exogenous variable, bank reserves, with the monetary aggregates they believed were driving inflation behavior.

As we have said before, if central banks controlled the amount of currency in the economy, that is, did open market operations with currency and somehow prevented recipients from returning it to the banking system, this would make it exogenous. As it is directly in the hands of the public, there would be no need to model how changes in C change M1 and M2. But virtually no central bank does this for obvious reasons. ${ }^{28}$

Reserves are fundamentally different from currency in that only banks may hold reserves and reserves are assets, not monetary liabilities of banks, hence they are not included directly in any of the monetary aggregates apart from M0. Currency is included in the monetary aggregates but as noted above, it is widely understood that almost no central bank in a market economy rations or attempts to control banknotes in circulation. Thus, not only is it important to the monetarist view to have a stable money income velocity (demand for money), it is also important to have a stable relationship between reserves and the broader monetary aggregates or to have a central bank operating procedure that adjusts reserves actively to keep the monetary aggregates under control.

The simple version of the money multiplier states that with bank deposits (money) subject to a reserve requirement, banks will create deposits until they exhaust any excess reserves they possess. The central bank can thus directly influence monetary aggregates by increasing or decreasing reserves in the system which will have a multiplicative effect on money, most simply, $1 / \mathrm{rr}$ where $\mathrm{rr}$ is the percentage of deposits banks must hold as reserves at the central bank. The text-book money multiplier also depends on the ratio of C/DD which we have already seen varied considerably, in the United States, over the last half of the $20^{\text {th }}$ century.

Almost all central banks insisted they did not operate in the way assumed by the monetarists. Although it is true they hold a monopoly on the supply of reserves held on their own balance sheets, they have a choice - as do all monopolists over whether to set the quantity of reserves to supply or the price at which they are supplied - they cannot set both. Prior to the GFC all the advanced country central banks were essentially providing the market with as much currency and reserves as desired at the opportunity cost of a target overnight interest rate. ${ }^{29}$ Banks needing reserves could borrow them at close to that rate either in the interbank market or at the regular open market operations conducted by every central bank.

Paul Tucker, then at the Bank of England had perhaps the most succinct statement of the dominant approach to monetary operations: "We are able to implement monetary policy

\footnotetext{
${ }^{28} \mathrm{We}$ are excluding the Soviet Union and some of its successor states and a few other outliers.

${ }^{29}$ The exception being Japan we will discuss shortly.
} 
because the economy has a demand for central bank money and, as monopoly suppliers, we can set the terms on which we provide it." 30

Similarly, in the U.S., "Starting in the late 1980s, the Federal Reserve ... did not target the amount of reserves, the quantity of deposits or loans on banks' balance sheets, or broad measures of the money supply.." 31

Cecchetti (2008), describes the reason why central banks had to provide reserves endogenously on demand : "...the job of the central bank is to assure that financial institutions have the necessary funds to conduct their daily business; that they have the 'liquidity' they need to make daily payments and transfers. Modern financial institutions need to replenish their funding every day. In the United States alone, literally trillions of dollars are transferred between banks each day to support the US\$50 trillion credit outstanding in the economy as a whole." ${ }^{32}$ Essentially, modern payments systems would not function without endogenous provision of reserves. The payments system aspect of the role of reserves explains the need and benefit of daylight overdrafts on commercial bank reserve accounts. Modern RTGS like Fedwire and Target 2 provide daylight overdrafts to facilitate the smooth functioning of the payments system. This means that reserve balances increase significantly during the operating day and then fall at the end of the day as overdrafts are eliminated through a natural process of netting or through the arrangement of interbank loans. Thus, the reserves multiplier, if one insists on calling it such is not only widely unstable over time but also highly variable intraday.

In referring to Mengle, Humphrey, and Summers (1987), Goodfriend and King (1988) cite the former as reporting total U.S. funds transfer daylight overdrafts of US\$ 76 billion per day, compared with total reserve balances with Reserve Banks of around US\$ 35 billion. ${ }^{33}$ This means that reserves double and shrink back to close to their original level during the hours the payments system is open.

The complete divorce between the textbook money multiplier model and reality is brought home by considering the situation at the individual bank level. In 2006, JP Morgan Chase, the largest U.S. bank held US\$ 1,352 billion in assets of which only US\$ 2.2 billion ( 0.16 percent) were reserves at FRBs. A negligible part of JP Morgan Chase's assets was financed with deposits subject to reserve. The Fed's decision in March 2020 to set the required reserve ratio at zero is perhaps the last nail in the coffin to the notion that advanced country central banks use reserve requirements in conjunction with changes in reserves to control money, credit or any other variable.

Indeed, the more modern view of reserve requirements is either as a tax on bank financial intermediation $^{34}$ or a convenient device, combined with reserve averaging, to facilitate

\footnotetext{
${ }^{30}$ Tucker (2004) p.3

${ }^{31}$ Goodfriend and King (1988) pps. 1-2.

${ }^{32}$ Cecchetti (2008)

${ }^{33}$ Goodfriend and King (1988) footnote 34.

${ }^{34}$ See Fama (1980) and Hardy (1993).
} 
interest rate targeting. ${ }^{35}$ In the latter case there is no reason why the reserve ratio could not be zero or nonexistent as it has been in Canada, Australia, Norway, Sweden, the UK and other countries for some time and has been in the United States since March 2020. ${ }^{36}$

Virtually all central bankers denied performing monetary operations in line with monetarist assumptions, i.e., manipulating reserves to achieve monetary targets relying on a stable link between reserves and bank liabilities. They often arguing precisely that such a procedure would be almost impossible to execute and lead to tremendous interest rate volatility ${ }^{37}$. Nevertheless, leading monetarists such as Lucas (1995) argued that "Central bankers and even some monetary economists talk knowledgeably of using high interest rates to control inflation, but I know of no evidence from even one economy linking these variables in a useful way..."38

Although there are serious economic research papers that expose the "money multiplier" as kaput, ${ }^{39}$ the point we wish to stress here is that all of the evidence and theory opposing it stresses the endogeneity of money.

"In the modern economy, most money takes the form of bank deposits. But how those bank deposits are created is often misunderstood; the principal way is through commercial banks making loans. Whenever a bank makes a loan, it simultaneously creates a matching deposit in the borrower's bank account, thereby creating new money." 40 [bold in the original] Thus the money supply is endogenous, a function of the loan generation process determined by the supply and demand for credit.

This insistence on the exogeneity of the nominal stock of money and its causal role in the monetary transmission mechanism, contrasts with the Keynesian view. A central bank in their view could alter interest rates and thereby influence money demand so that "monetary control" would be possible although ultimately endogenous and monetary policy would have an impact on the economy through the direct impact of changes in interest rates on credit, consumption and saving. Such an interpretation, although it is in accord with the way in which virtually all central bankers describe their operating proceeds, runs against the simplicity of the monetarist policy prescriptions which emphasizes a steady pre-announced target for monetary expansion and the power of monetary expansion and contraction even in the absence of an impact of policy on credit aggregates.

Indeed, since the 1960s there has been a stunning difference in view between central bankers and monetary theorists in how monetary operations are conducted, and how CBDL has been

\footnotetext{
${ }^{35}$ See Gray (2011).

${ }^{36}$ The U.S. Board of Governors reduced reserve requirement ratios on net transaction accounts to 0 effective March 26, 2020. This eliminated reserve requirements for all depository institutions.

${ }^{37}$ See Bindseil (2004)

${ }^{38}$ Lucas (1995), page 249.

${ }^{39}$ For example, see Carpenter and Demiralp (2012).

${ }^{40}$ McLeay, Radia and Thomas (2014). P. 1.
} 
created and destroyed, that has in more recent times become somewhat reconciled by Michael Woodford.

"...thinking about monetary policy as interest rate policy is one of the hallmarks of the new consensus that has made possible increasingly fruitful interaction between academics and central bankers. " 41

"Before the recent crisis, monetary policy implementation across countries had generally converged on an approach in which the policy stance is defined exclusively in terms of a short-term interest rate-henceforth referred to as 'interest rate policy'," ${ }^{42}$

Laidler (2006) in a sense pointed out that the revived QTM was not truly tested (in OECD countries) as central bankers did not behave as they ought to have according to the model: "...where Friedman had advocated that the monetary base be used as the policy instrument whereby money growth was controlled, actual policy relied on the manipulation of an interest rate. Central banks in effect used a model of the generation of the money supply in which the latter variable was posited to adjust passively to the behavior of real income and prices..."

\section{B. Bank of Japan's experiment with quantitative easing (QE).}

“The Bank of Japan's policy between 2001 and 2006 provides one example of quantitative easing. It had the following key features: first, it involved a shift in the operational target for money market operations from the uncollateralized overnight call rate to the outstanding balance of current account deposits at the Bank of Japan, or in short the bank reserves..."43

When the Bank of Japan introduced a quantity target for CBDL in its QE experiment, it first forecast the demand for currency (which it supplied on demand) then subtracted this amount from the target for CBDL and thereby derived the operational target for bank reserves.

"A commitment such as increasing cash in circulation at a certain rate literally gives a picture of quantitative easing, and thus is quite attractive as a message to the public. Since a central bank cannot control the amount of cash in the purse of the public, all operations of the central bank have to be geared toward reserves to implement base money targeting. " 44 (italics added).

\footnotetext{
${ }^{41}$ Goodfriend (2007).

42 Borio and Disyatat (2009).

${ }^{43}$ Bini Smaghi (2009), p. 5.

${ }^{44}$ Okina (1999), p. 174. In short, Japan's first experiment with targeting a large increase in bank reserves failed to elicit a commensurate increase in inflation expectations and ten years after even higher increases in reserves were witnessed in other advanced economies without commensurate effects it seems wise to focus communication on the duration for which interest rate targets will be held low while explaining that monetary aggregates are tangential to objectives. Some central bank researchers and policymakers have done this though the point may be in need of reinforcement owing to increasing magnitudes of reserves increases in reserves increases in advanced economies and more widespread adoption of unconventional policies in emerging markets.
} 
So here we have a clear and precise commitment to increasing the monetary base to attain an inflation objective.

Friedman's view of the potential of this policy, particularly that monetary aggregate expansion alone is sufficient to engender inflation, is evident below.

"The Bank of Japan can buy government bonds on the open market, paying for them with either currency or deposits at the Bank of Japan, what economists call high-powered money. Most of the proceeds will end up in commercial banks, adding to their reserves and enabling them to expand their liabilities by loans and open market purchases. But whether they do so or not, the money supply will increase. There is no limit to the extent to which the Bank of Japan can increase the money supply if it wishes to do so. Higher monetary growth will have the same effect as always. After a year or so, the economy will expand more rapidly; output will grow, and after another delay, inflation will increase moderately. A return to the conditions of the late 1980s would rejuvenate Japan and help shore up the rest of Asia." 45

How exactly the money supply beyond M0 would expand without an increase in bank lending is rather unclear as is what the mechanism would be to foster inflation without an expansion of credit.

The type of "open market expansion" described by Friedman is merely an exchange of treasury bills held by the public/banks for reserves. The counterpart of the decline of credit from the economy to the government (sale of treasury bills) would be exchanged for credit from the public to banks (customer deposits are effectively lending to banks) and a corresponding increase of net lending from banks to the central bank (bank deposits are a form of lending to the central bank). Consolidating the central bank and government, an open market security purchase is simply a swap of sovereign financing through securities for borrowing from the banking system.

Not only is such an operation unlikely to have a stimulative macroeconomic impact, ${ }^{46}$ it could be contractionary as it replaces fungible treasury securities that can be held by investors worldwide and used as collateral in global capital markets with deposits held at the central bank and tradeable only among banks authorized to hold such accounts ${ }^{47}$

Although the results we present in Section III are conclusive and include Japan among the sample of 143 countries considered over the period 1990-2019 we feel it important to go into more detail on Japan as it is the only advanced economy to attempt monetarist style policy implementation in the $21^{\text {st }}$ century. Figure one displays the 30 -year correlation in Japan between inflation and the same monetary variables shown for the full sample in Section III.

\footnotetext{
${ }^{45}$ Friedman (1998).

${ }^{46}$ This is precisely the point of Wallace (1981)

${ }^{47}$ See Singh and Stella (2012) and Singh (2020).
} 
Figure 1. Correlation of Monetary Aggregates with Inflation for Japan (1990-2019)

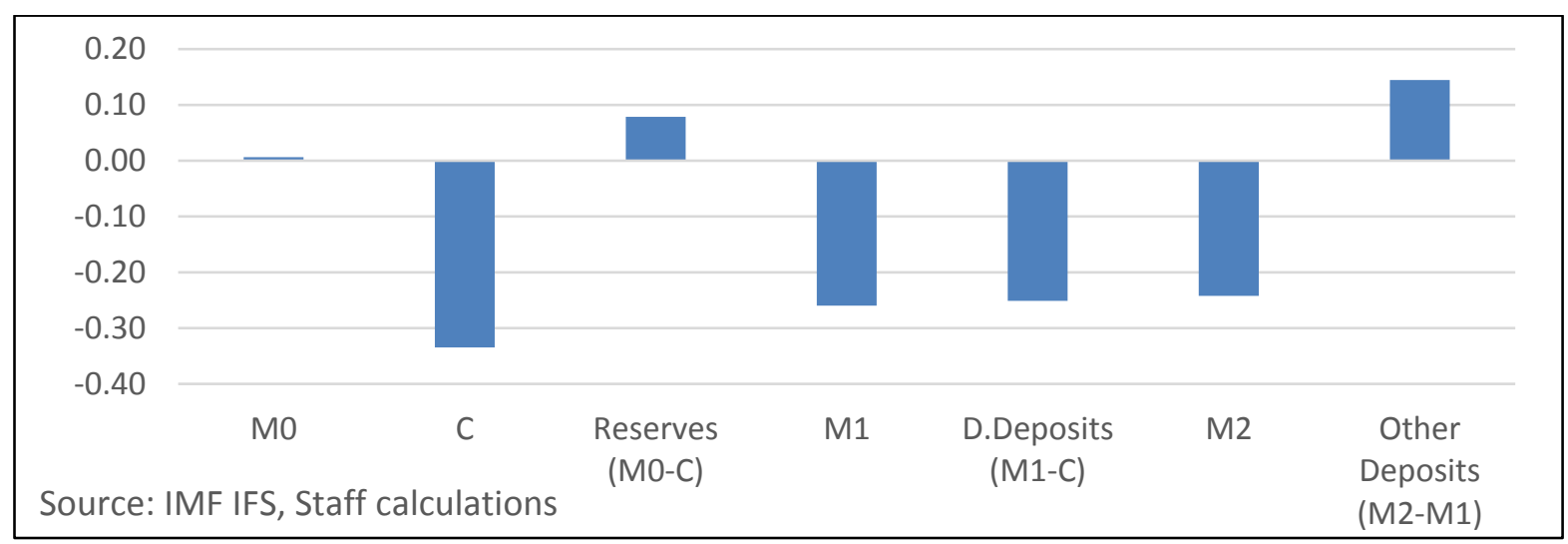

The correlation with $\mathrm{M} 0$ is essentially zero and negative for most of the other aggregates- $\mathrm{a}$ similar result to the full sample.

Figures 2 and 3 show that the correlation between changes in the monetary base lagged by 12 months and Japanese bank credit expansion during 1991-2020 is exactly zero. Thus, the expansion in reserves had neither a commensurate impact on credit nor directly on inflation. ${ }^{48}$

Figure 2. Japan: Bank Reserves and Total Loans 1991-2020 (in 100 billion yen)

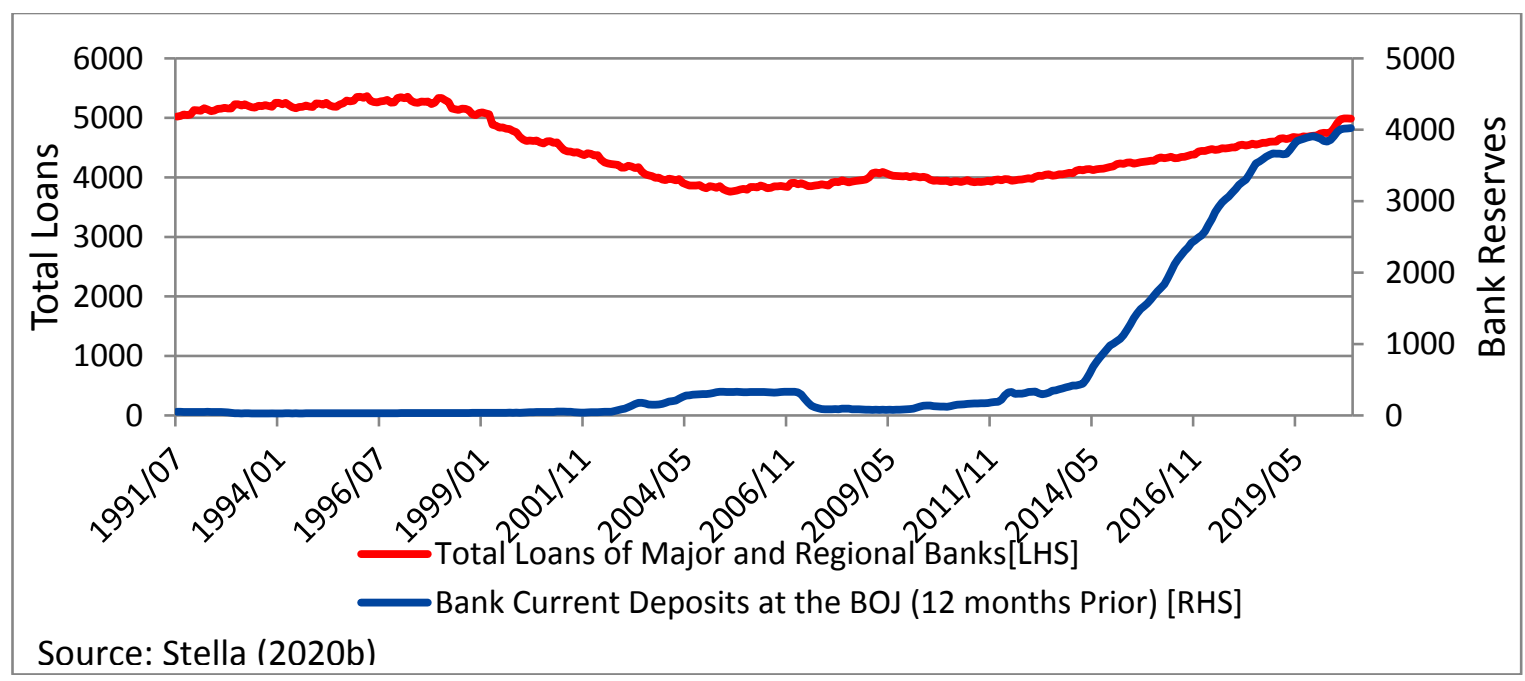

\footnotetext{
${ }^{48}$ See Bowman, Cai, Davies, and Kamin (2011) for more discussion of the relationship between BOJ's expansion in reserves and its impact on bank credit including consideration of the counterfactual situation wherein BOJ did not engage in QE.
} 
Figure 3. Japan: Change in Total Loans and in Bank Reserves (12 months prior) 1991-2020

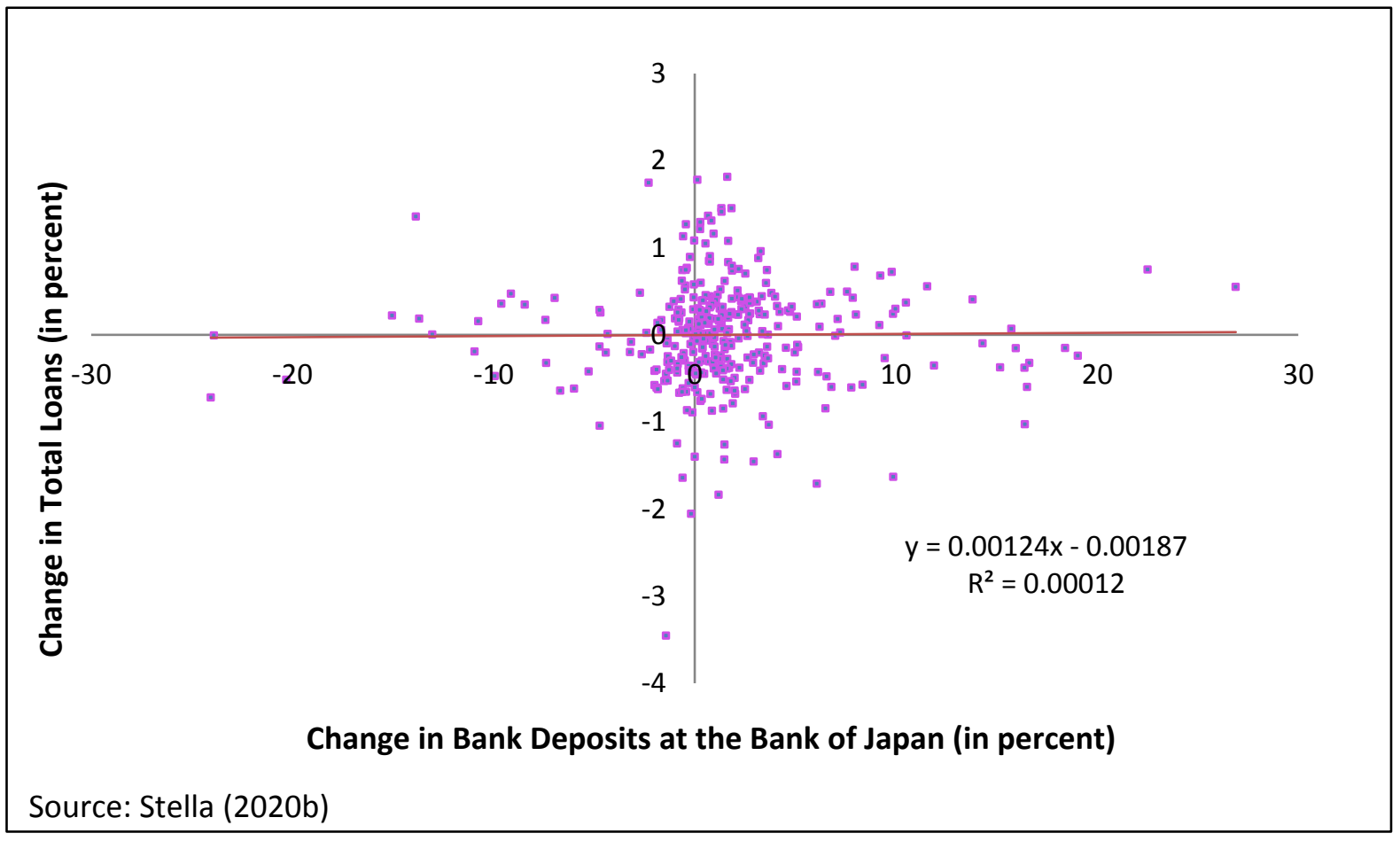

The absence of a material impact on bank lending from a large pre-announced increase in reserves brings into question the causal nature of money and the "money multiplier" theory. Experience with superabundant reserves, as in Japan, has revealed that other factors such as capital constraints and the creditworthiness of borrowers play a key role in determining credit and money growth and that, in those cases, reserves creation against government securities purchases plays no role in the policy transmission mechanism.

The enormous expansion of reserves in other countries since the GFC, in the United States, UK, Eurozone, and Switzerland have similarly not been associated with marked expansions in credit nor have they had a significant impact on inflation. The failure of the expansion of reserves to result in commensurate increases in inflation has thus been demonstrated now in many countries despite the exogeneity of reserves.

Though at the beginning of central bank balance sheet expansion many economists, journalists and even some central bankers thought there would be inflation if reserves were not soon absorbed, ten years later these prognostications are being taken less seriously.

It thus seems unlikely that expectations of inflation can be well managed by stressing the impact of policy on monetary aggregates. Neither the first Bank of Japan experiment with QE nor subsequent announced expansions in reserves appear to have had a clear impact on 10-year JGB yields (Figure 4). 
Figure 4. 10 Year Japan Government Bond (JGB) Yields

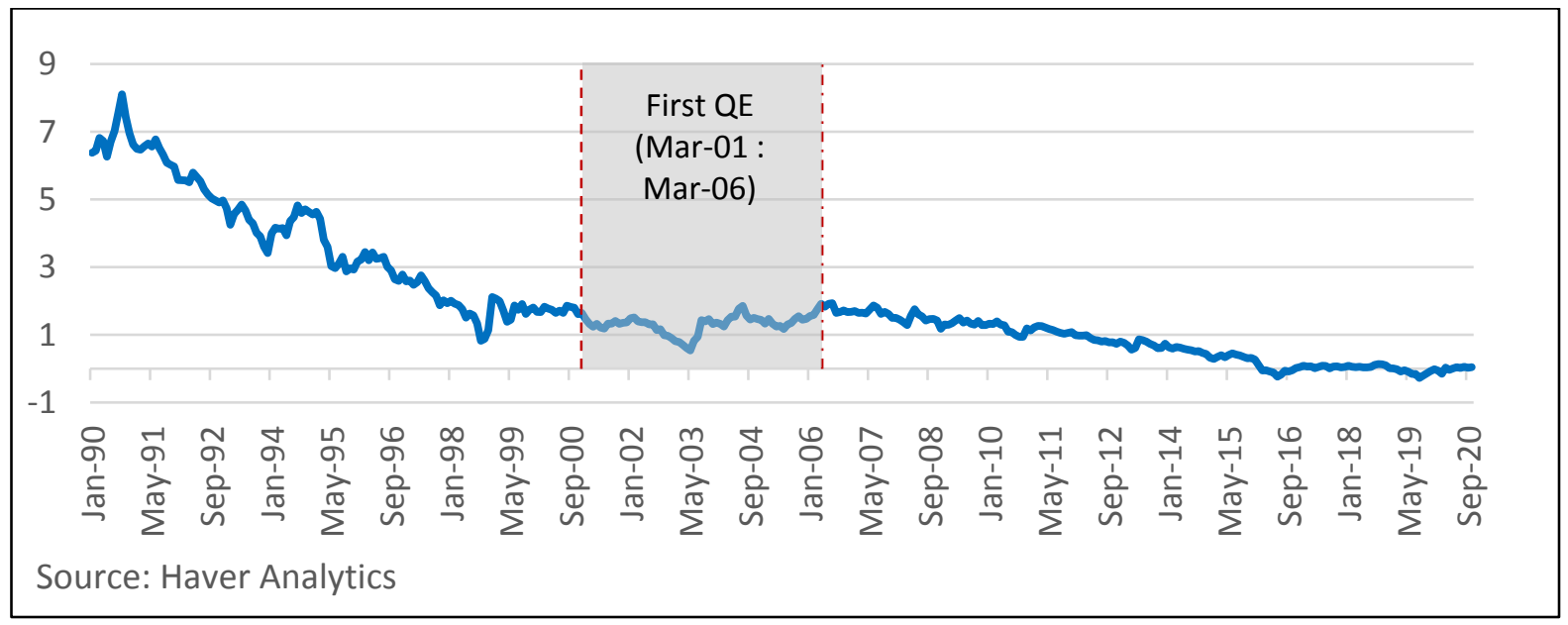

Some central banks, such as the Bank of England and Federal Reserve have stressed the irrelevance or limited importance of monetary aggregates in their thinking. For example:

"The huge quantity of bank reserves that were created has been seen largely as a byproduct of the purchases that would be unlikely to have a significant independent effect on financial markets and the economy. This view, however, is not consistent with the simple models in many textbooks or the monetarist tradition in monetary policy, which emphasizes a line of causation from reserves to the money supply to economic activity and inflation.... To date, this channel does not seem to have been effective... the quantity of bank loans is still falling, and money supply growth has been subdued." 49

Furthermore, after the GFC, capital requirements were increased and in many countries a leverage ratio was imposed or raised (this is the ratio of capital to total assets). Thus, capital availability became obviously more important a constraint to lending than "reserves". As the regulations were designed when it was not anticipated central bank balance sheets would become so large with knock-on effects on the size of commercial bank balance sheets, these requirements, in particular the simply leverage ratio (which included capital requirements for commercial bank deposits held at central banks), the increase in reserves actually constrained bank lending inadvertently. ${ }^{50}$ Some countries, such as the UK exempted deposits at the central bank from the calculation of the leverage ratio in 2016, while others, including the United States, relaxed the leverage and other prudential ratios after the expansion of bank excess reserves associated with COVID-19 associated central bank balance sheet expansion.

\footnotetext{
${ }^{49}$ Kohn (2010)

${ }^{50}$ See McCauley and McGuire (2014) and Stella (2015).
} 
Thus, the impact of superabundant reserves on the size of commercial bank balance sheets, combined with leverage and other capital requirements may paradoxically have a contractionary impact on bank lending to the real economy. ${ }^{51}$

Certainly, the Fed made it clear that the point of its Asset Purchase Program was not to increase the "money supply" but to lower interest rates on longer term debt such as home mortgages and other long-term credit. ${ }^{52}$

Up until this point we have largely discussed evidence from advanced country central banks. In the next section we will consider a much wider cross-section of countries over an extended period of time.

\section{QUANTITY THEORY OF MONEY-THE LAST 50 YEARS (EMPIRICS)}

\section{A. Revisiting Alternative Monetary Facts}

In his Nobel Address Robert Lucas implied that the quantity theory of money and the proportionality between money growth and inflation was one of the most empirically welldocumented theories in all of economics. He spent some time during his address illustrating this proposition with the results of the research paper-_"Some Monetary Facts". 53 Although there is ample empirical work supporting the proportionality of money and prices, Lucas highlighted this paper as it used pooled data from many countries with a standardized (IMF) database, comprised many different monetary regimes, and covered a long period of time30 years. That the inclusion of many different regimes - hard currency pegs, floating exchange rate regimes as well as various forms of managed pegs and floats might seem surprising since Lucas himself was clear that the "way money enters into models matters" 54 - he presumably found the results so convincing they could be held up as "universally" valid.

Lucas also cited the fact that McCandless and Weber (1995) (MW) results were uniformly in line with theory no matter the monetary aggregate chosen. They thus appeared doubly universal. Valid regardless of the monetary regime and of the aggregate chosen. This too is somewhat surprising given that, if it matters how money enters a model, surely it would be important to consider forms of money that are clearly endogenous such as M1 and M2 different from M0 which Lucas and the monetarists saw as exogenous. ${ }^{55}$

\footnotetext{
${ }^{51}$ See Martin, McAndrews and Skeie (2011).

${ }^{52}$ Federal Open Market Committee (2009).

${ }^{53}$ McCandless and Weber (1995).

${ }^{54}$ Lucas (1995) "We need to be explicit...about the way the new money gets into the system, and it matters how this is done." p. 257.

${ }^{55}$ Central banks invariably view M0 creation as being against either domestic debt or foreign exchange purchases thus in line with Wallace (1981). See the discussion of Wallace (1981) elsewhere in this paper.
} 
Lest we think that was merely a transitory reference, Lucas referred to the same paper and same graph approximately 20 years later. ${ }^{56}$

Figure 5A. Money Aggregates and Inflation, 1960-1989
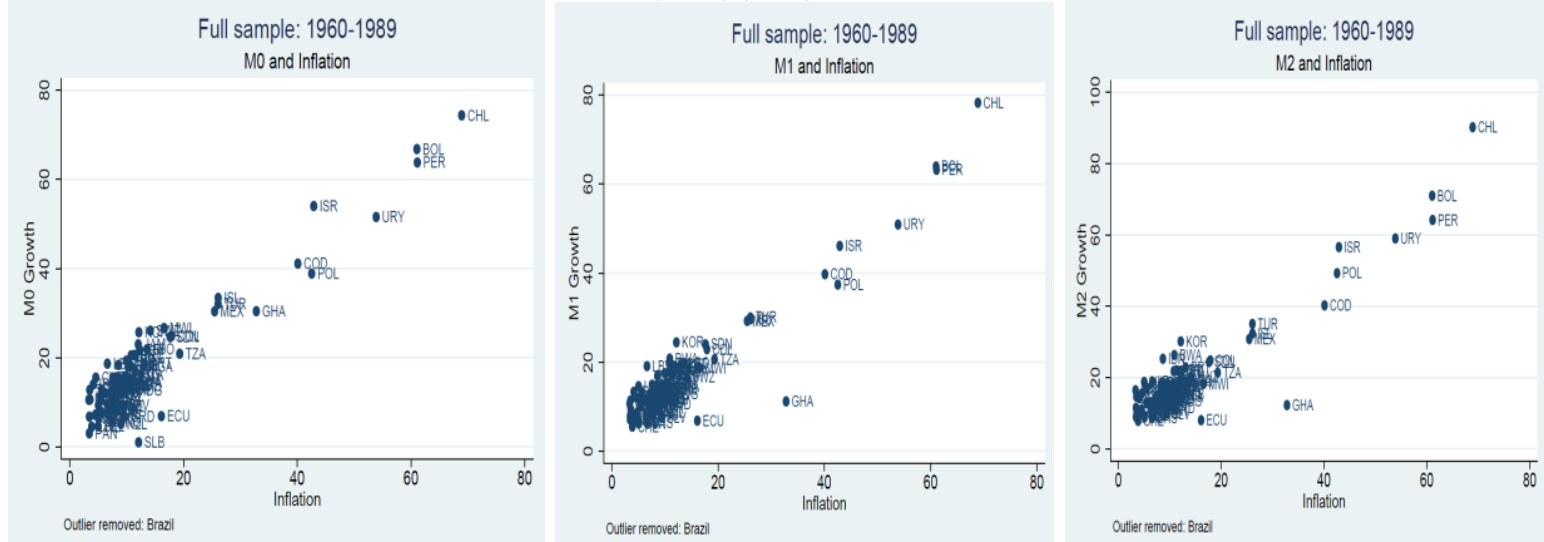

Figure 5B. Money Aggregates and Inflation, 1990-2019
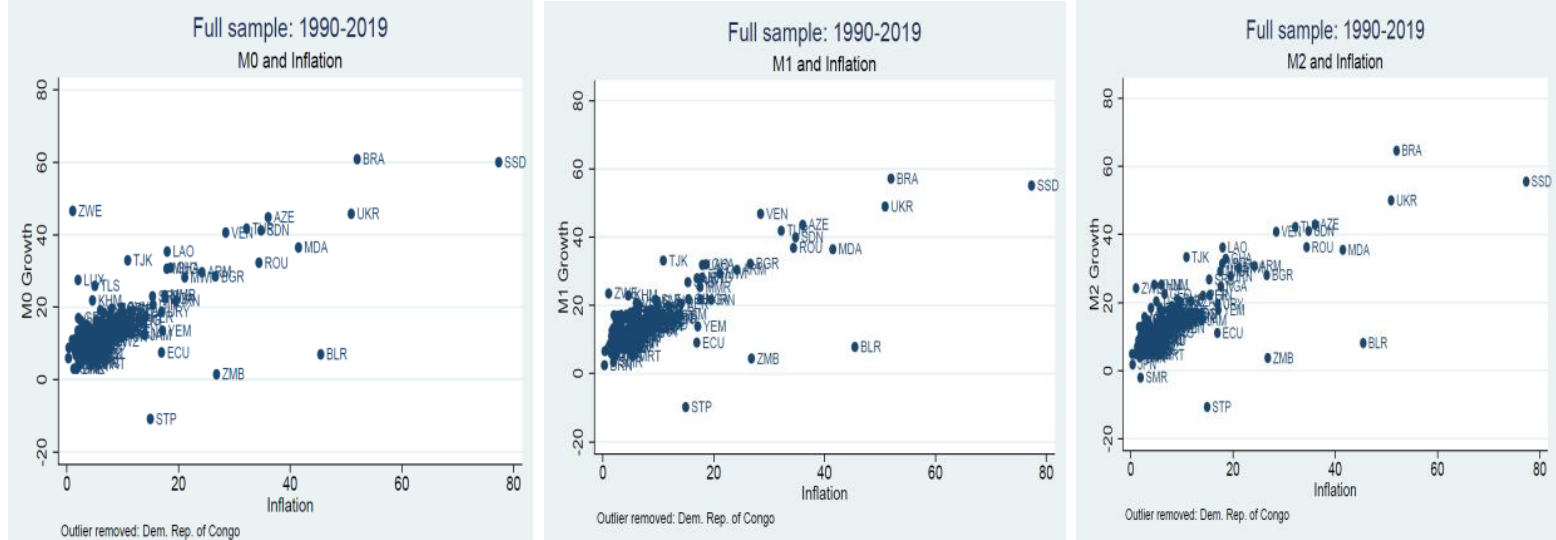

Figure 5C. Money Aggregates and Inflation, 2001-2019
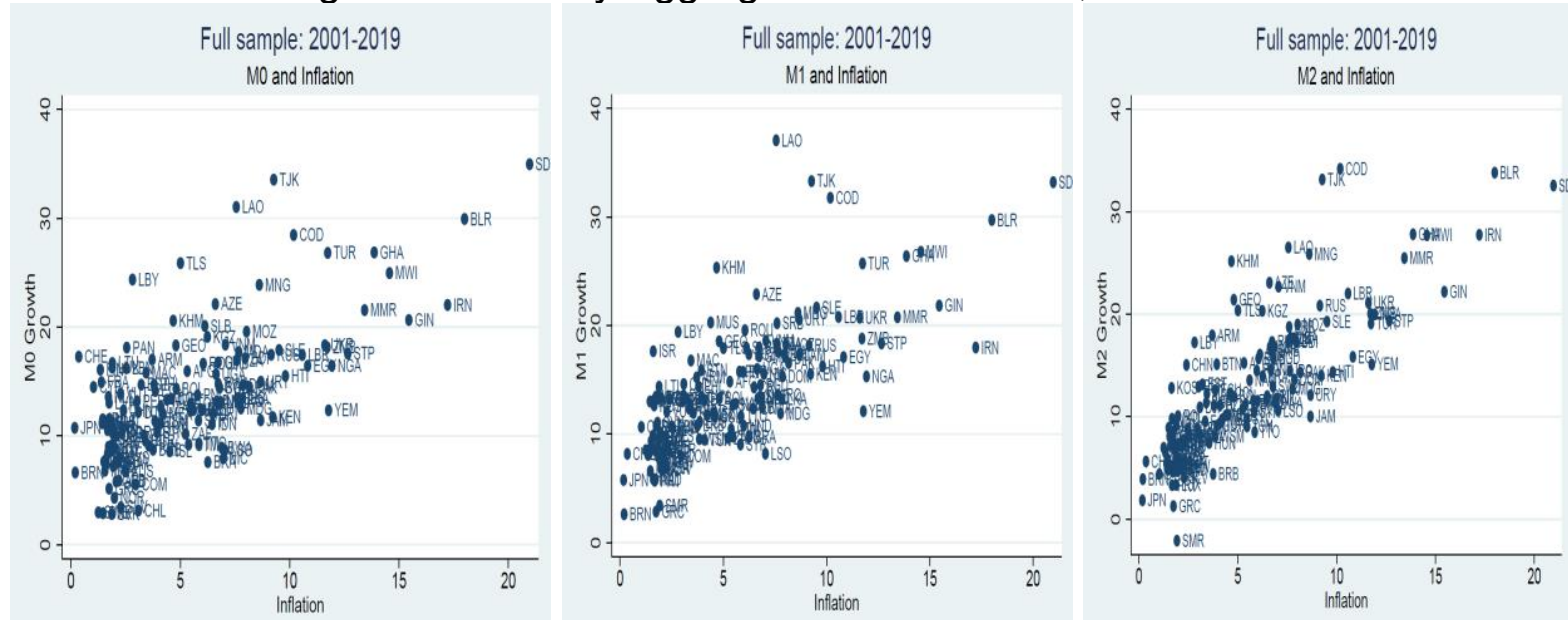

${ }^{56} 2014$ Homer Jones Memorial Lecture - Robert E. Lucas Jr. 
In this section we reexamine the results of MW with respect to the relation between money and prices. MW also estimated the long run relationship between money and real GDP (the "neutrality" proposition") but that proposition has almost universal acceptance, we confine ourselves to the relationship between money and prices. See Figure 5 (Panels 5A, 5B, 5C) for raw scatter plots of long-term correlations between growth rates of money aggregates and inflation.

As a first step we re-estimated MW's equations using a data set as close as possible to their data over the thirty-year time they considered, 1960-1989. Our coefficients are shown in the first three columns of Table 2 (i.e., M0, M1 and M2). None of the nine coefficients is statistically significantly different from one - thus we have duplicated the proportionality result obtained by MW.

\section{Table 2. Long-term Geometric Growth Rates of MS (and Components) and Inflation (Correlation Coefficients), 1960 to 1989}

\begin{tabular}{lcccccccc}
\hline & $\begin{array}{c}\text { No. of } \\
\text { countries }\end{array}$ & M0 & M1 & M2 & $\begin{array}{c}\text { Currency } \\
\text { (C) }\end{array}$ & $\begin{array}{c}\text { Reserves } \\
\text { (M0-C) }\end{array}$ & $\begin{array}{c}\text { D.Deposits } \\
\text { (M1-C) }\end{array}$ & $\begin{array}{c}\text { Other } \\
\text { Deposits } \\
\text { (M2-M1) }\end{array}$ \\
\hline Full Sample & 88 & 0.9461 & 0.9398 & 0.9299 & 0.9604 & $0.6436^{*}$ & $0.8905^{*}$ & 0.9258 \\
OECD & 19 & 0.9051 & 0.9298 & 0.9312 & 0.8496 & 0.7258 & 0.9292 & 0.8534 \\
LATAM & 12 & 0.9737 & 0.9749 & 0.9752 & 0.9758 & 0.9565 & 0.9724 & 0.9691 \\
\hline Outliers: Brazil & \\
&
\end{tabular}

In the four additional columns we break down the various monetary aggregates into subcomponents and compute the long-term correlations. We do this to test whether the irrelevance results that hold for M0, M1, and M2 continue to hold for their various subcomponents.

As seen in the full sample coefficients for Reserves and Demand Deposits they do not; the asterisks indicate that both coefficients are significantly different from 1, and lower than 1. Interestingly, the coefficient on currency is not different from one, and indeed is the closest of all components to 1 while the coefficient on reserves is significantly different from one and is by far the lowest among all the components. This points to a significant difficulty in ascribing causality from money to inflation.

In virtually no country does the central bank ration, i.e. control the supply of banknotes, hence currency is determined by market demand and cannot be considered as exogenously set the central bank. Therefore, currency cannot be considered as causing inflation, indeed the sensible interpretation is that inflation and anticipated inflation drives the demand for banknotes. This leaves bank reserves as the remaining variable theoretically under the direct control of the central bank and indeed the variable mentioned when monetarists discuss monetary control procedures. Thus given the stress placed by Lucas on the irrelevance of the monetary aggregate to be considered in the "proportionality equation", it is ironic that reserves is the worst performing and, logically, the good performance of the monetary base 
must come entirely from the performance of currency, a variable known to be endogenous. This suggests already in the period 1960 to 1989, that scratching the surface of the QTM one finds inconsistencies in the empirical "headline" correlation/causation and the dynamics of the theory.

In Table 3 we use the same MW methodology to consider the subsequent 30-year relationship between monetary aggregates and their subcomponents with inflation.

Table 3. Long-term Geometric Growth Rates of MS (and Components) and Inflation (Correlation Coefficients), 1990 to 2019

\begin{tabular}{lcccccccc}
\hline & $\begin{array}{c}\text { No. of } \\
\text { countries }\end{array}$ & M0 & M1 & M2 & $\begin{array}{c}\text { Currency } \\
\text { (C) }\end{array}$ & $\begin{array}{c}\text { Reserves } \\
\text { (M0-C) }\end{array}$ & $\begin{array}{c}\text { D.Deposits } \\
\text { (M1-C) }\end{array}$ & $\begin{array}{c}\text { Other } \\
\text { Deposits } \\
\text { (M2-M1) }\end{array}$ \\
\hline Full Sample & 143 & $0.7504^{*}$ & $0.7728^{*}$ & $0.7787^{*}$ & $0.7841^{*}$ & $0.5484^{*}$ & $0.7250^{*}$ & $0.7342^{*}$ \\
OECD & 20 & $-0.4666^{*}$ & $0.4460^{*}$ & $0.5882^{*}$ & $0.5706^{*}$ & $-0.3130^{*}$ & $0.4137^{*}$ & $0.3995^{*}$ \\
LATAM & 11 & 0.7840 & 0.8537 & 0.8209 & 0.5715 & 0.2752 & 0.8151 & $0.1605^{*}$ \\
\hline
\end{tabular}

Outliers: Congo, Ecuador

*indicates statistically different from 1 at 5 percent significance level

Here, all the coefficients on all the variables in the full sample and the OECD sub-sample are statistically significantly different from 1 . As is the case with the period from $1960-1989$, the coefficient on Reserves (the only "possible" exogenous variable) is the lowest of all coefficients and in the case of the OECD is negative. A negative coefficient signifies that an increase in reserves is associated with a long-run decline, rather than an increase in inflation!

This result is driven by the massive increase in reserves post-GFC that has been accompanied by lower than average inflation. Though it is important to reiterate the weak correlation of the supposedly exogenous element of money (reserves) and inflation was already apparent in the full sample more than 30 years ago.

In Table 4 we consider the last 19 years of the sample where the coefficient on Reserves continues to be the lowest of all the subcomponents and lower than in the 1990-2019 sample.

Table 4. Long-term Geometric Growth Rates of MS (and Components) and Inflation (Correlation Coefficients), 2001 to 2019

\begin{tabular}{lcccccccc}
\hline & $\begin{array}{c}\text { No. of } \\
\text { countries }\end{array}$ & M0 & M1 & M2 & $\begin{array}{c}\text { Currency } \\
\text { (C) }\end{array}$ & $\begin{array}{c}\text { Reserves } \\
\text { (M0-C) }\end{array}$ & $\begin{array}{c}\text { D.Deposits } \\
\text { (M1-C) }\end{array}$ & $\begin{array}{c}\text { Other } \\
\text { Deposits } \\
\text { (M2-M1) }\end{array}$ \\
\hline Full Sample & 140 & $0.6685^{*}$ & $0.72768^{*}$ & $0.8225^{*}$ & $0.6328^{*}$ & $0.4006^{*}$ & $0.6573^{*}$ & $0.7606^{*}$ \\
OECD & 18 & $-0.3713^{*}$ & $0.4070^{*}$ & $0.6739^{*}$ & $0.3897^{*}$ & $-0.3214^{*}$ & $0.3220^{*}$ & $0.5366^{*}$ \\
LATAM & 12 & 0.6837 & 0.7479 & 0.6909 & 0.5192 & 0.7678 & 0.7317 & $0.0785^{*}$ \\
\hline
\end{tabular}

Outliers: None

*indicates statistically different from 1 at 5 percent significance level

Our results clearly provide alternative facts to MW's "Some Monetary Facts". Indeed, they show the recent failure of the proportionality argument for all measures of money and its 
subcomponents as well as the most spectacular failure occurring with the variable most plausibly exogenous to inflation.

Fifteen years after the publication of Milton Friedman's Program for Monetary Stability (1961), the bedrock of the argument for his money growth rate rule - the stability of the demand for money - appeared to have become badly unstable. ${ }^{57}$ Not only would an unstable demand for money divorce monetary targets from the objective of price stability but also for predicting developments in the real economy. ${ }^{58}$ The problem of the stability of parsimonious models of money demand apparent in the mid-1970s became informally known by the evocative title of Stephen Goldfeld's 1976 Brookings Paper, The Case of the Missing Money. ${ }^{59}$

Goldfeld (1973) had successfully fitted a parsimonious quarterly model of M1 demand to income and interest rates for the period spanning $1952-72 .{ }^{60}$ Several years later, Goldfeld (1976) found that his earlier model performed very poorly out-of-sample during 1974-76. Specifically, it dramatically over-predicted the demand for money during 1974-1976.

Hence the notion that money that should have been in the data had gone "missing".

Upon closer examination, Goldfeld (1976) showed that the demand for the two components of M1, currency (C) and DD had performed quite differently. Although the model underpredicted actual currency demand only slightly, it had terribly over-predicted actual holdings of DD. In other words, there was no missing C, but a lot of missing DD. Goldfeld (1976) and the notes from the Brookings Panel discussion offer fascinating insight into the way leading economists of the day were examining this key empirical puzzle with seemingly important implications for the formulation of monetary policy. ${ }^{61}$ Goldfeld's work in the 1970s U.S. matches our facts on payments system innovation presented in Section II and presaged the evaporation of the stable money demand function in the U.S., other advanced countries and eventually worldwide.

With the benefit of hindsight, we now know that the search for a stable monetary demand function in the U.S., as well as in virtually all the advanced countries, was quixotic.

Whether this divergence of theory from reality was significant for the actual conduct of monetary policy and operations is not obvious. Even during the apogee of monetarism, monetary policy was viewed by central bankers as being about setting an interest rate target and allowing the monetary base - and by reference - monetary aggregates to be demand

\footnotetext{
${ }^{57}$ See Laidler (2006) for more on the resurgence of monetarism led by Friedman.

${ }^{58}$ Since monetary aggregates are typically available weekly, while quarterly GDP figures are available with a lag and subject to significant revisions, a close correlation of money and GDP — regardless of any causal relationship - would allow policymakers to infer real time developments in GDP through the monetary aggregates.

${ }^{59}$ Goldfeld (1976)

${ }^{60}$ Goldfeld (1973)

${ }^{61}$ The panel included three eventual Nobel Laureates in Economics, James Tobin, Edmund Phelps and Christopher Sims, as well as William Baumol, a pioneer in modelling the transactions demand for money.
} 
determined, i.e. endogenous. Though it took economic theory some time, the current mainstream consensus view, articulated by, e.g., Michael Woodford in his textbook Interest and Prices, leaves virtually no scope for money.

Central bankers have long insisted that monetary policy consists in determining the optimal policy interest rate at discrete points in time and monetary operations consist of supplying as much central bank money as is demanded by the market at an interest rate close to the target. In this conceptualization, the central bank's ability to consistently hit its policy target generates credibility in its statements about policy rates in the future and how they correspond to the objective mandated. The impact of policy rates on the risk-free yield curve impact the economy, thus the impulse of usually infrequent changes to interest rates is transmitted to the economy through the impact on the yield curve and the latter's impact on bank loan and deposit rates, securities prices and yields, and ultimately on consumption and investment decisions.

\section{B. Implications for Debt and Monetary Financing}

We have shown that the naïve QTM relationship between various measures of money and prices has broken down and is virtually unrecognizable in modern data. We have also explained the reasons why this relationship has broken down due to many factors, not the least of which is technological change. We have also shown that the employment of unorthodox monetary measures since the GFC, accompanied by the rapid enormous expansion of reserve money-well beyond what had hitherto been demanded for payments systems purposes - has strengthened, rather than reversed, our findings.

Our findings over a broad range of countries raise the question how to explain the wellknown historical evidence associating high money growth and high inflation. One facile response would be to say that such a relationship exists, but the causality runs from prices to money rather than the other way around. But this is somewhat unsatisfactory. A better response examines what Lucas referred to earlier as "the way money enters the model".

The way in which base money - either directly with bank reserves or indirectly with currency - enters the economy in situations where the central bank is not subject to fiscal dominance involves a swap of financial assets. Reserves are swapped for local currency sovereign debt or foreign exchange reserves. It is an exchange of equal values, assuming it takes place in an "open market" transaction, i.e. is an "open market operation".

The standard open market operation was analyzed in Wallace (1981). Considering open market operations in a theoretical model, Wallace showed that such operations should be "irrelevant" in the economy. Another way of looking at this result is to say there is little difference between an overnight deposit at the central bank (reserves) and a short-term treasury bill. And in reality, virtually all central banks accept treasury bills as collateral with little or no haircut against a loan of reserves. Central bankers accepted the irrelevance notion implicitly though did control the overnight interest rate target through small technical adjustments in the supply of reserves. 
Money enters into Lucas (1972) and many other theoretical monetary models in a very different way. It appears ex nihilo, out of thin air and appears in consumers' pocketbooks. Friedman used the famous notion "helicopter" money to describe this thought experiment. In these models and thought experiments, nothing is taken in exchange from the economy for cash. Indeed, a monetary injection in this context is akin to fiscal transfers financed with freshly created money and given to consumers that know it cannot be taxed away from them in the future. It thus solves two problems with monetarist theory, the injection is clearly exogenous and permanent and spending will take place on final goods and services.

In those circumscribed models, and in historical episodes of sudden large fiscal expenditures financed with money - under conditions where the necessities of fiscal finance override monetary considerations - the quantity of monetary expansion will be related closely to inflation. ${ }^{62}$

The difference between CBDL created trading it in the open market for other government liabilities and money created by giving it away to finance fiscal expenditures is central to understanding why monetary augmentation has little impact on prices in the former context and significant immediate and lasting impact on prices in the latter.

Were we to confine our statistical analysis to episodes of permanent money finance we would undoubtedly find a very close relationship between money and prices but in a broader sample, as we have shown, the correlation largely vanishes. This distinction is crucial to bear in mind when evaluating proposals to finance large expansions in fiscal spending with money. Those who have recognized that recent large increases in CBDL have not caused inflation and then have proceeded to suggest virtually unlimited permanent monetary finance as a non-inflationary inexpensive way to fund increased fiscal expenditure have conflated these two different ways in which CBDL enters the economy.

Unsustainable fiscal expenditures will be inflationary regardless of whether they are financed in the first instance with money or bonds. Thus, the advocates of increased permanent monetary finance, though they do not usually express themselves this way, essentially are naively assuming that money finance is less expensive that bond finance for any given level of deficit spending. Ironically, they are doing so in a climate where most advanced country government debt is selling at negative interest rates and currency earns a higher rate of return. (Not that this is particularly relevant for, as we have seen, it is not possible to force people to hold massive amounts of currency beyond what they wish to hold). In modern times, money finance must be through bank reserves.

The problem with relying on financing through massive excess reserves is that the financial system simply does not have any use for them. As we showed in the case of the U.S., the payments system was functioning well with comparatively low levels of reserves, on the order of US\$ 20 billion. Reserves are now in the trillions of dollars. The same can be said of the other countries with expanded central bank balance sheets. Subjecting those balances,

${ }^{62}$ Sargent and Wallace (1981) say that if fiscal policy dominates monetary policy, "if the fiscal authority's deficits cannot be financed solely by new bond sales, then the monetary authority is forced to create money and tolerate additional inflation. set up a model where fiscal deficits beyond a certain threshold must be financed with money regardless of the central bank's monetary target". 
which the system is holding only as an unintended consequence of QE operations to negative interest rates, is tantamount to a tax. A tax that would, if kept in place for an extended period be passed partially to depositors and debilitate financial intermediation. Paying interest on reserves would essentially be converting reserves (money finance) into short term interest earning government debt.

The advocates of increased reliance on permanent outright monetary finance are essentially arguing that the pre-GFC allocation of sovereign currency, reserves and bonds was inefficient. ${ }^{63}$ That the proportion of CBDL was too small in comparison with holdings of bonds. The fallacy of that argument is clear both in history and in theory.

As we have explained, bank reserves play an important role in the payments system but technological developments have enabled quadrillions of dollars, euros, and yen to be transferred every year without more than a small quantity of reserves being needed. Reserves in excess of this amount are simply deadweight on banks' balance sheets (Singh, 2017; Singh 2014). Reserves suffer in comparison with treasury securities because they can only be held by banks, cannot be used as collateral efficiently like securities, and are subject to capital requirements. Treasury securities may be held by anyone residing anywhere, serve as collateral and support global capital markets, and are not subject to capital requirements when held by real money investors. Thus, if we compare the two instruments, beyond a minimum threshold required for payments, securities sell at a premium to reserves and are a more efficient and less costly way for the sovereign to finance itself. (Refer Annex 1)

Turning to financial history, it is obvious that apart from a few notable exceptions - often countries suffering from high inflation and/or rationing of basic goods and services - since the 1980s countries have made great strides in developing their domestic debt markets and escaping from reliance on foreign currency debt.

The development of domestic debt markets in countries that once had a choice only between foreign debt denominated in foreign exchange and domestic monetary finance has taken a great amount of effort, but it has paid important benefits. This is why so many countries that suffered through extended periods relying on monetary finance in the 1970s and 1980s and subsequently made great strides to develop domestic debt markets, Mexico, Brazil, Chile, Peru, Colombia, Israel and Thailand, for example, are issuing debt rather than money to finance deficits even during the exigencies of the COVID crisis (Otaviano 2020). The presumably see little rationale in turning back to the failed financial policies of yesteryear, compelling the economy to accept more permanent outright monetary finance than is desired and undermining the progress they have achieved with modern debt management methods.

\section{Conclusions}

Central bank direct liabilities (CBDL) continue to play an important role in the economy. Bank reserves serve as final settlement media within highly efficient RTGS systems moving

\footnotetext{
${ }^{63}$ The advocates of monetary finance often talk as if "conservative" central banks engage in zero monetary finance. This is far from the truth. Every central bank that issues its own currency provides a certain amount of permanent finance this way and has for decades if not centuries. The issue is about "how much" is optimal, the amount determined by the market or by the government, not about "whether".
} 
trillions of dollars, euros and sterling - and hundreds of trillion yen - through wholesale financial markets every business day. Many central banks, in countries including Switzerland, UK, United States, Japan and the Eurozone are actively engaged in projects to make RTGS and retail payments systems safer, faster, and less expensive. ${ }^{64}$ Innovation is also taking place rapidly in the private sector, from fintech startups to some of the world's largest and long-established banks.

What we have illustrated in this paper, however, is that past, present and future payments innovation has and will continue to increase payments speed and reduce the quantity of settlement balances needed for a given level of monetary transactions. In other words, the faster and more secure payments become, the less CBDL are needed..$^{65}$ This trend, not well noticed prior to the GFC, has been completely obscured by the extraordinary and massive increase in CBDL which has occurred since the GFC.

Understanding the role of CBDL in modern payments systems is key to the three fundamental points we make in the discussion, (i) the complete breakdown of the relationship between the quantity of CBDL and inflation is simply a continuation of a trend that had been apparent for decades - there is no causal relationship, (ii) although the quantity of CBDL has recently become exogenous - determined by central bank policy - this has not altered (i) and indeed has exposed it quite clearly; and (iii) permanent monetary finance should not be the preferred route in the near zero (or negative) rate environment. Furthermore, the simple abstract theoretical representations of the quantity theory of money are incapable of analyzing properly the recent increase in CBDL because they fail to distinguish between money created in exchange for bonds and money created to permanently finance higher fiscal spending.

The recent increase in CBDL has not been in the form of "helicopter money" for which there is no purpose other than to spend, rather CBDL has merely substituted for financial assets already in the hands of the public. Increases in CBDL that have resulted from the central bank purchases of domestic government debt have merely changed the composition of sovereign domestic debt and are essentially a debt management operation, a swap of treasury debt for less efficient central bank liabilities that may only be held by domestic banks whereas treasury securities may be held by any economic entity at home or abroad, and (iii) the notion that "helicopter money" or permanent monetary finance is superior, less expensive, or more efficient that bond finance rests on fragile and fallacious foundations.

The current negative interest rates on most developed country medium term debt suggests that it is a superior way to finance temporary surges in expenditure such as those related to COVID-19. Moreover, prospering emerging market countries with ample experience with monetary finance in the 1980s and 1990s - Chile, Brazil, Peru, Mexico and Israel for example - have conspicuously steered clear of reliance on monetary finance during the current unprecedented crisis owing to their having established vibrant and well-functioning domestic government debt markets. Given the evidence we have presented about secular

\footnotetext{
${ }^{64}$ See Bech, Shimizu and Wong (2017).

${ }^{65}$ See Copic and Franke (2020) and Singh and Long (2020).
} 
declines in the demand for CBDL, both in the form of reserves and currency, any government strategy that relies on increasing permanent monetary finance is swimming against tides both historical and technological. 


\section{Annex 1. Collateral and Money Aggregates}

In this box, we integrate the collateral angle to the traditional money metrics. Typically, the role of collateral plays in money markets is often overlooked in macroeconomics. The renewal of quantitative easing (QE) in response to the Covid-19 pandemic means central banks will continue to play a major role in the collateral markets for some time to come. QE removes good collateral - typically sovereign bonds, but even corporates and equities - from the market. This has implications for associated rates, such as repo, securities lending, prime brokerage financing and derivatives margins - the nuts and bolts of market plumbing

Many textbooks still use the conventional IS-LM model to describe the relationship between interest rates and economic output. Here, the IS curve represents investment and savings. The LM curve represents liquidity demand and money supply. The point where they intersect represents the equilibrium in output and money markets. One drawback of this model is that it does not explicitly account for exogenous shifts in collateral. The LM curve is typically derived from the equation $M=f(Y, r)$, where the supply of money is a function of output (Y) and benchmark interest rates (r). The latter is assumed to be sufficient to determine the entire yield curve, inclusive of all money market rates and risk premia (Figures A1 and A2).

Figure A1. IS/LM Model

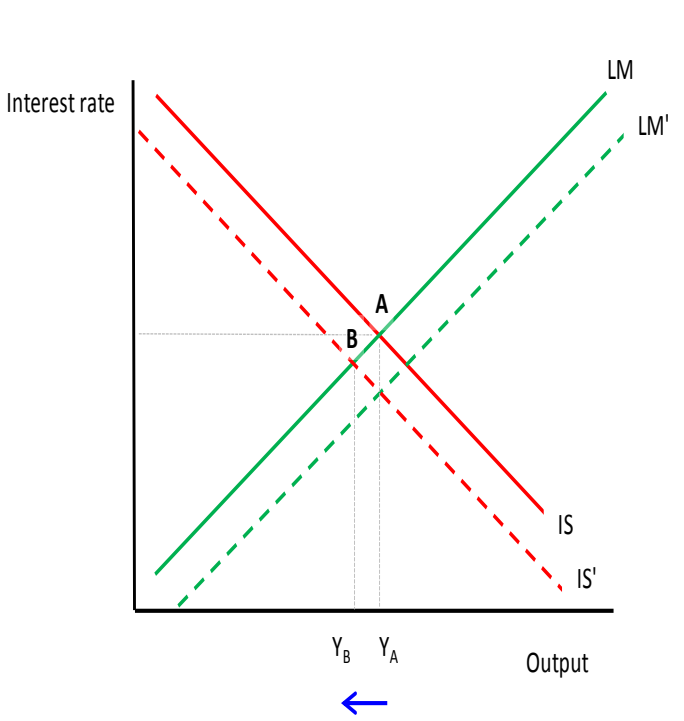

Figure A2. Contraction in collateral market and shifts in IS-LM

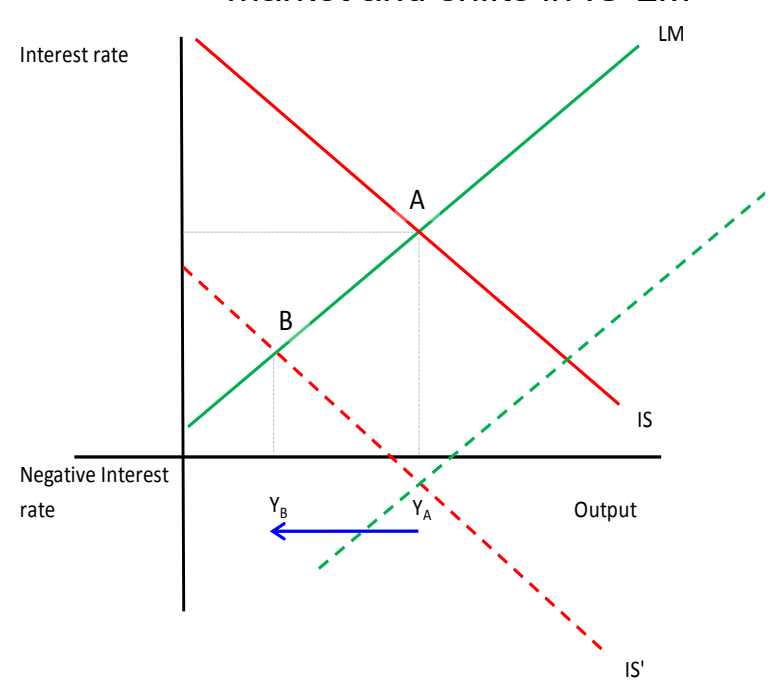

The role of pledged collateral markets in the transmission of monetary policy is ignored. A simple way to address this is to re-write this equation as $\mathrm{M}=\mathrm{f}\left(\mathrm{Y}, \mathrm{r}, \mathrm{c}_{\mathrm{p}}\right)$, where $\mathrm{c}_{\mathrm{p}}$ is a variable measuring the efficiency of pledged collateral (that can be reused). This 'new' LM curve, factoring in the role of collateral in money markets, adds a new wrinkle to the monetary policy framework. ${ }^{1 /}$ When collateral markets are constrained, and their lubrication effect is lower for a given supply of money $(\mathrm{M})$, a larger change in benchmark interest rates ( $\mathrm{r}$ ) will be needed to produce the same change in output $(\mathrm{Y})$

All else equal, this implies the efficiency of monetary policy transmission is reduced when collateral supply shrinks. More broadly, $\mathrm{c}_{\mathrm{p}}$ can be interpreted as a parameter governing the efficiency of monetary policy transmission given the role of collateral as a lubricant in secured 
finance markets. This enriched IS-LM model more accurately describes how changes in collateral supply after the global financial crisis have impacted economic outcomes.

When collateral use drops, financial intermediation slows, with effects similar to the drying of interbank markets. The stock of collateral can decline as investors become more concerned about counterparty risk, making them less willing to lend securities, and resulting in idle collateral sitting in segregated accounts. It can also be affected by large scale QE, which drains good collateral from the system, or a widening of the pool of eligible assets, which increases pledgeability, as part of central bank's collateral framework.

Figure A3. Old LM curve shifts parallel

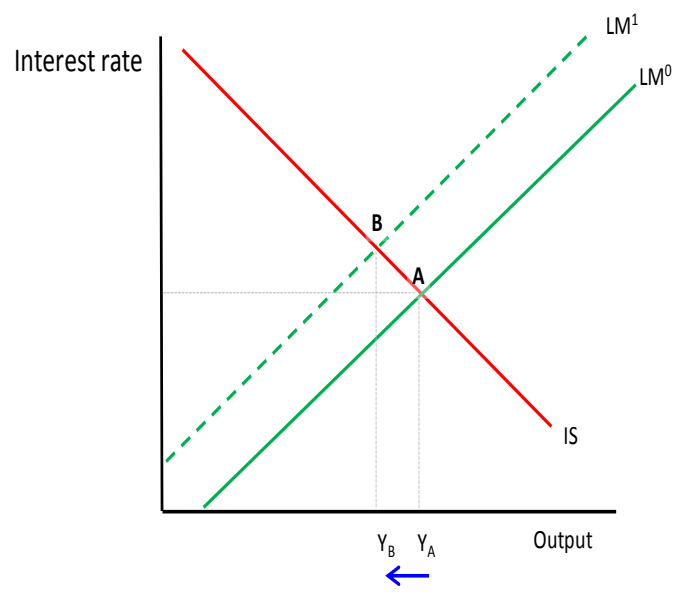

Figure A4. New LM curve pivots

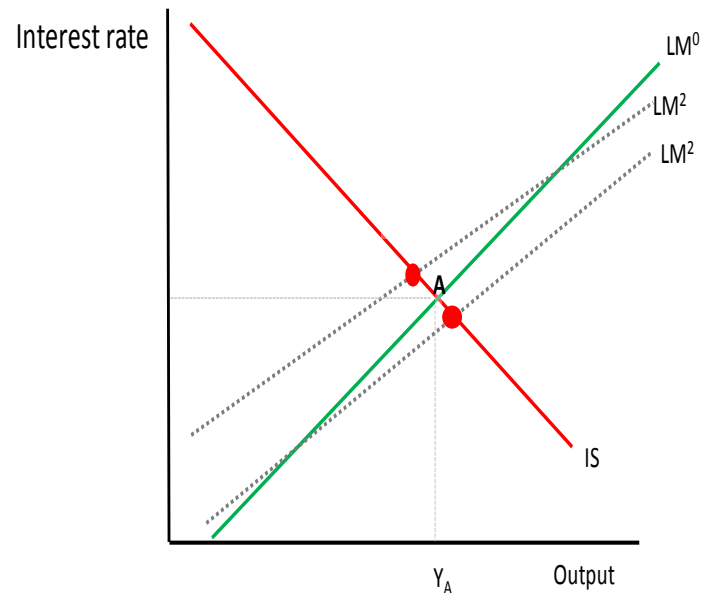

In the 'new' IS-LM model, changes in monetary policy may not always result in a parallel shift in the LM curve, as depicted in the conventional IS-LM framework; here, the LM curve may pivot and intersect the IS curve at a different point, depending on the slope. Recent research suggests that QE may increase output initially but may have a decreasing effect as QE increases in scale (Geanakopolos and Wang, 2020). The new IS-LM model supports these findings.

Figure A3 depicts the crash in pledged collateral (notably, the alphabet soup of AAA and AA securitizations) in the aftermath of the Lehman-crisis. This market was growing sizably since 2001-2007. Pledged collateral volumes, including the price effect, fell from around US\$10 trillion before the crisis to around US\$5.5 trillion afterwards (Singh 2011); volumes are inching back slowly to US $\$ 8.5$ trillion Overall financial collateral efficiency, $\mathrm{c}_{\mathrm{p}}$, declined considerably as a result. Figure A4 demonstrates the impact of QE, shown by a rightward shift in the LM curve, and a countervailing move due to the effect on collateral efficiency of the central bank purchasing vast amounts of treasury securities and other good collateral.

Even with a large debt issuance pipeline, there is dealer balance sheet constraints to "digest" all U.S. Treasuries. Dealers have shied away from making a market in U.S. Treasury repo in September 2019, and then again shied away from making a market in off-the-run US Treasuries in March 2020. So, a rebound in pledged collateral "reuse" rate depends on dealer balance sheet space.

This new IS-LM model has important policy implications. The Covid-19 pandemic has forced interest to near-zero rates and QE is back; As policymakers chart a course through the crisis, and looking beyond money aggregates as discussed in Section II and III, they should recognize the 
trade-off between the negative effects of constraining collateral markets and the positive effects of QE. 


\section{REFERENCES}

Bank of England (2014), The operations currently used in the Sterling Monetary Framework, Bank of England Website September 25.

Bech, Morten, Shimizu, Yuuki and Paul Wong (2017), The quest for speed in payments, BIS Quarterly Report, March.

Benigno, Pierpaolo and Salvatore Nisticò (2015) Non-Neutrality of Open-Market Operations, Centre for Economic Policy Research DP10594, May.

Bernanke, Ben S. (2006), Monetary Aggregates and Monetary Policy at the Federal Reserve: A Historical Perspective, Remarks at the fourth ECB Central Banking Conference, Frankfurt, November 10.

, 2016, Brookings Institute, What Tools Does The Fed Have Left

https://www.brookings.edu/blog/ben-bernanke/2016/04/11/what-tools-does-the-fed-haveleft-part-3-helicopter-money/

Bindseil, Ulrich (2004), The Operational Target of Monetary Policy and the Rise and Fall of Reserve Position Doctrine, European Central Bank Working Paper \# 372.

Bini Smaghi, Lorenzo (2009), Conventional and unconventional monetary policy, BIS Review 52.

Board of Governors of the Federal Reserve (1943), Banking and Monetary Statistics 19141941. , (1976), Banking and Monetary Statistics 1941-1970.

Bordo, Michael D. (1987), Equation of Exchange, Palgrave Macmillan (eds) The New Palgrave Dictionary of Economics. Palgrave Macmillan, London. https://doi.org/10.1057/978-1-349-95121-5 530-1.

Borio, Claudio (2019), On money, debt, trust and central banking, BIS Working Paper No 763.

Borio, Claudio and Piti Disyatat (2009), Unconventional monetary policies: An appraisal, BIS WP \#292.

Bureau of Economic Analysis, U.S. Department of Commerce (2007), An Introduction to the National Income and Product Accounts, available online.

Carpenter, Seth and Selva Demiralp (2012), Money, reserves, and the transmission of monetary policy: Does the money multiplier exist? Journal of Macroeconomics 34, 59-75.

Cecchetti, Stephen G. (2008), Crisis and Responses: The Federal Reserve and the Financial Crisis of 2007-2008, NBER Working Paper 14134. 
Chailloux, Alexandre, Ulrich H. Klueh, Simon Gray, Seiichi Shimizu and Peter Stella (2008), Central Bank Response to the 2007-08 Financial Market Turbulence: Experience and Lessons Drawn, IMF Working Paper 08/210.

Christensen, Clayton (1997), The Innovator's Dilemma: When New Technologies Cause Great Firms to Fail, Harvard Business Review Press.

Evans, George W. and Seppo Honkapohja (2001). Learning and Expectations in Macroeconomics, Princeton University Press.

Cochrane, John H. (2001). Long term debt and optimal policy in the fiscal theory of the price level, Econometrica 69(1), 69-116.

Copic, and Franke, 2020, Celo Labs paper "Influencing the Velocity of Central Bank Digital Currencies"

David Bowman \& Fang Cai \& Sally M. Davies \& Steven B. Kamin, 2011. "Quantitative easing and bank lending: evidence from Japan," International Finance Discussion Papers 1018, Board of Governors of the Federal Reserve System (U.S.), revised 2011. Disyatat, Piti (2008), Monetary Policy Implementation: Misconceptions and their Consequences, BIS Working Paper \# 269.

Evans, George W. and Seppo Honkapohja (2003). Expectations and the Stability Problem for Optimal Monetary Policies, The Review of Economic Studies, 70, p. (807-824).

Fama, Eugene F. (1980), Banking in a Theory of Finance, Journal of Monetary Economics, 6.

Federal Open Market Committee (2009), Minutes from FOMC Meeting, June 23-24, 2009.

Federal Reserve Banks of Boston, Richmond, and San Francisco (2017), 2015-16 Diary of Consumer Payment Choice, available online.

Fischer, Stanley (2016), (Money), interest and prices-Patinkin and Woodford, Speech at "A Conference in Honor of Michael Woodford's Contributions to Economics", New York City, May 19.

Fisher, Irving (1922), The Purchasing Power of Money, Its Determination and Relation to Credit Interest and Crises, $2^{\text {nd }}$ edition, Reprints of Economic Classics, New York, New York, USA (1963).

Friedman, Milton (1998), Reviving Japan, Hoover Digest No. 2, April, Hoover.org/research/reviving-Japan

Garvy, George (1959), Deposit Velocity and Its Significance, Federal Reserve Bank of New York. 
Geanakopolis, John and Haobin Wange, 2020, Quantitative Easing, Collateral Constraints, and Financial SpilloversAmerican Economic Journal, Vol. 12 No. 4 October 2020

Goldfeld, Stephen M. (1973), The Demand for Money Revisited, Brookings Papers on Economic Activity, 3: 1973

Goldfeld, Stephen M. (1976), The Case of the Missing Money, Brookings Papers on Economic Activity, 3:1976.

Goodfriend, Marvin (2007), How the World Achieved Consensus on Monetary Policy, Journal of Economic Perspectives Vol. 21, \# 4.

Goodfriend, Marvin and Robert G. King (1988), Financial Deregulation, Monetary Policy, and Central Banking, Federal Reserve Bank of Richmond Economic Review, Vol. 74 No. 3.

Gray, Simon (2011), Central Bank Balances and Reserve Requirements, IMF Working Paper \# 11/36.

Hardy, Daniel (1993), Reserve Requirements and Monetary Management: An Introduction, IMF Working Paper \# 93/35.

Humphrey, David B, Mengle, David and Bruce J. Summers (1987), Intraday Credit: Risk, Value and Pricing, Federal Reserve Bank of Richmond Economic Review, Vol. 73, no. 1.

Humphrey, Thomas M. (1974), The Quantity Theory of Money: Its Historical Evolution And Role In Policy Debates, Federal Reserve Bank of Richmond Economic Review, May/June 1974.

Keister, Todd, Antoine Martin and James McAndrews (2008), Divorcing Money From Monetary Policy, FRBNY Economic Policy Review, September.

Keynes, John Maynard (1924), A Tract on Monetary Reform, Prometheus Books (USA) edition, 2000.

Kohn, Donald L. (2010), The Federal Reserve's Policy Actions during the Financial Crisis and Lessons for the Future, Speech at Carleton University, Ottawa, Canada, May 13 at Federal Reserve Board website

Laidler, David (2006), Three Lectures on Monetary Theory and Policy: Speaking Notes and Background Papers, Oesterreichische Nationalbank Working Paper 128.

Lucas, Robert E. Jr (1972), Expectations and the Neutrality of Money, Journal of Economic Theory, 4, pgs. 103-124 
Leeper, E. (1991). Equilibria under 'active' and 'passive' monetary policies. Journal of Monetary Economics 27(1), 129-147.

Lucas, Robert E. Jr (1995), Monetary Neutrality, Nobel Prize lecture Stockholm Sweden, December 7.

Marcet, Albert and Juan P. Nicolini (2003), Recurrent Hyperinflations and Learning, American Economic Review, Vol. 93 No. 5, December.

McCauley, Robert and Patrick McGuire (2014), Non-US banks' claims on the Federal Reserve, BIS Quarterly Review, March 2014.

Martin, Antoine, James McAndrews and David Skeie (2011), A Note on Bank Lending in Times of Large Bank Reserves, FRB of New York Staff Report no. 497

McCandless Jr., George T., and Warren E. Weber (1995), Some Monetary Facts, Federal Reserve Bank of Minneapolis Quarterly Review, Summer.

McCallum, Bennett T. (1985), Monetary vs. Fiscal Policy Effects: A Review of the Debate, NBER Working Paper 1556.

(2002) Recent Developments in Monetary Policy Analysis: The Roles of Theory and Evidence, FRB Richmond Economic Quarterly 88(1).

McLeay, Michael, Amar Radia and Ryland Thomas (2014), Money creation in the modern economy, Bank of England Quarterly Bulletin, Q1.

Okina, Kunio (1999), Monetary Policy under Zero Inflation: A Response to Criticisms and Questions Regarding Monetary Policy, Bank of Japan Monetary and Economic Studies, Vol. 17 \# 3, December.

Otaviano Canuto, (2020), Quantitative Easing in Emerging Market Economies https://www.cmacrodev.com/quantitative-easing-in-emerging-market-economies/

Patinkin, Don (1969), The Chicago Tradition, The Quantity Theory, And Friedman, Journal of Money, Credit and Banking, Vol. 1, No. 1, February.

Roosa, Robert V. (1953), Federal Reserve Operations in the Money and Government Securities Markets Federal Reserve Bank of New York Pamphlet, FRASER/StLouisFed.org.

Sargent, Thomas J. and Neil Wallace (1981), Some Unpleasant Monetarist Arithmetic, Federal Reserve Bank of Minneapolis Quarterly Review, Fall.

Singh, Manmohan, (2020), Collateral Markets and Financial Plumbing, Risk Books. 
,(2017) Why shrinking the Fed balance sheet may have an easing effect, April 24

https://www.ft.com/content/a9290f7c-b8e8-34cd-b457-ed835dca6395

, (2014), How QE can jam financial plumbing, Dec 3.

https://www.ft.com/content/d40c5cc4-4e29-11e4-bfda-00144feab7de and Peter Stella (2012), Money and Collateral, IMF Working Paper 95/12.

and Caitlin Long (2020), How Programmable Digital Assets May Change

Monetary Policy, https://ftalphaville.ft.com/2020/09/03/1599134259000/How-

programmable-digital-assets-may-change-monetary-policy/

Sims, Christopher (2013), Paper Money, American Economic Review, Vol. 103, No. 2.

Son, Hugh (2020), JPMorgan creates new unit for blockchain projects, says the technology is close to making money, CNBC.com October 27.

Stella, Peter (2015), Exiting Well, available at www.CentralBankArchaeology.com.

(2020a), How Countries Manage Large Central Bank Balance Sheets, In:

Asset Management at Central Banks and Monetary Authorities, ed. Jacob Bjorheim, Springer, Cham.

(2020b), The Huge Chasm That Arose Between Monetarism and Reality:

Japan's Experiment with $Q E$, available at www.CentralBankArchaeology.com.

Teles Pedro, Harald Uhlig, João Valle e Azevedo, Is Quantity Theory Still Alive?, The Economic Journal, Volume 126, Issue 591, 1 March 2016, Pages 442-

464, https://doi.org/10.1111/ecoj.12336

Tucker, Paul (2004), The Central Bank's Balance Sheet: Where Monetary Policy Meets Financial Stability, Speech to mark the fifteenth anniversary of Lombard Street Research, London, July 28.

Wallace, Neil (1981), A Modigliani-Miller Theorem for Open-Market Operations, The American Economic Review, 71(3), 267-274.

Woodford, Michael (2003), Interest and Prices: Foundations of a Theory of Monetary Policy, Princeton University Press. 